\title{
أنهاط الحوار الأسرى وعلاقتها بإدارة الذات لدى الأبناء
}

\author{
إعداد \\ أ. م.دم/ إيناس ماهر بدير \\ الأستاذ المسـاعد \\ بقسم إدارة مؤسسـات الأسـرة والطفولة \\ كلية الاقتصاد المنزلي - جامعة حلوان \\ أ.م.نه./ رشا عبد العاطحسـ راغب \\ الأستاذ المسـاعد \\ بقسهم إدارة مؤسسات الأسـرة والطفولة \\ كلية الاقتصداد المنزلي - جامعة حلوان
}

مجلة بحوث التربية النوعية ـ جامعة المنصورة

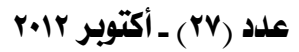




\title{
أنهاط الهوار الأسرى وعلاقتها بإدارة الذات لدى الأبناء
}

\author{
إعداد \\ أ تم.د/إيناسماهر بدير \\ أ.م.د ـ/رشاعبد العاطرراغت
}

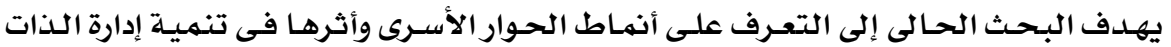

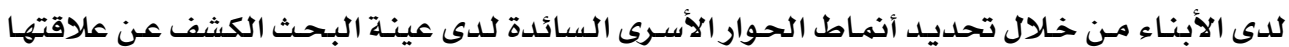

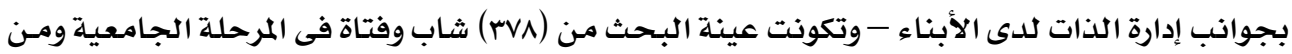

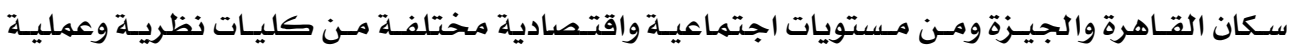

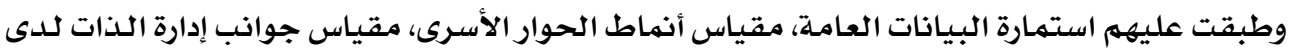

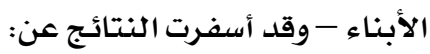

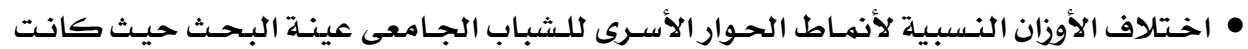

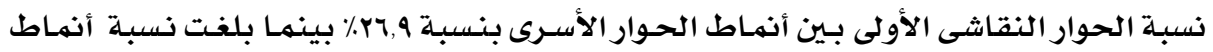

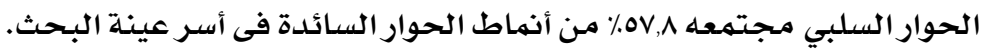

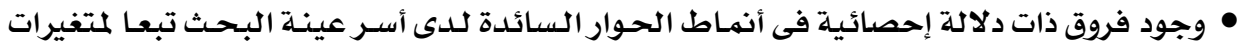

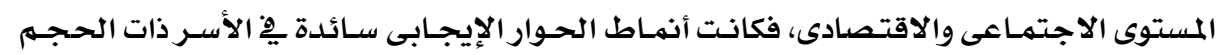

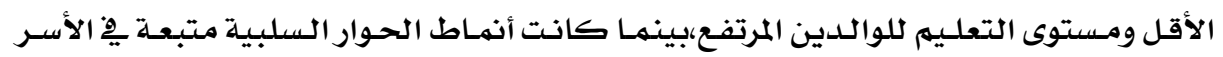

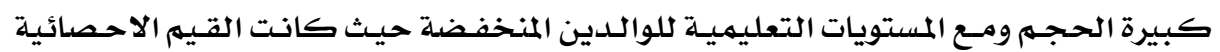

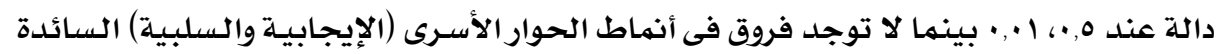

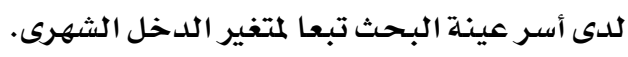

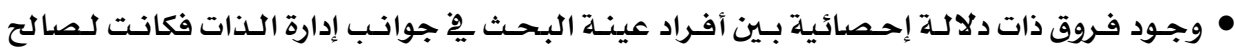

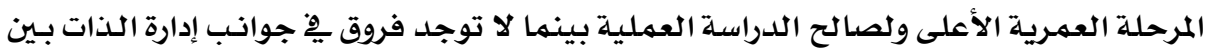

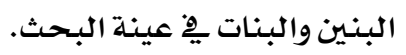

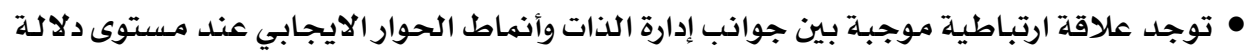

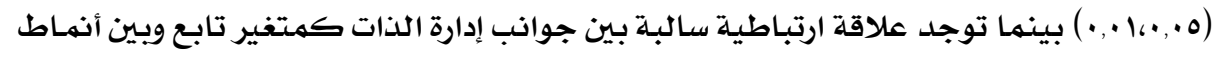

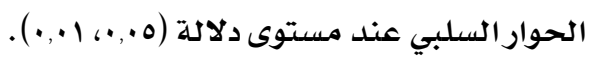

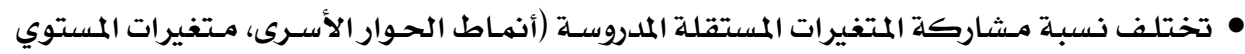

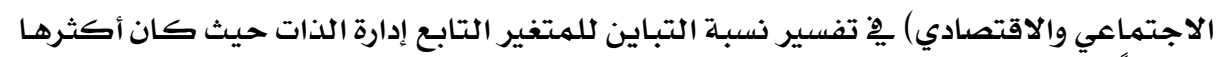

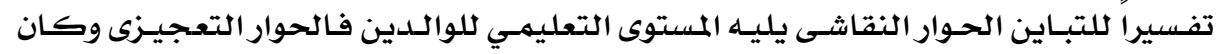

$$
\text { أقلها الحوار العدواني. تلفين. }
$$

وقد اقترحت الباحثتان برنامـج إرثادي لتوعية الشباب بفنيات إدارة الحوار الأسرى.

* الأستاذ المساعد بقسه إدارة مؤسسات الأسرة والطفولة كلية الاقتصاد المنزلي - جامعة حلوان 


\title{
Dialogue prisoners patterns and their relationship to self-management among youth
}

\begin{abstract}
:
The research aims present to identify patterns of dialogue prisoners and their impact in the development of self-management in children by identifying patterns dialogue prisoners prevailing among a sample search detected relationship aspects of self-management in children - and sample consisted of (378) young men and women in undergraduate and residents of Cairo Giza and social and economic levels of different theoretical and practical faculties and applied them public data form, scale patterns dialogue prisoners, measure aspects of self-management of children - the results have resulted in:

- different relative weights of dialogue patterns for young prisoners university research sample, where the proportion of first Anakashy dialogue between dialogue patterns prisoners by $26.9 \%$ while the percentage of negative patterns of dialogue combined $57.8 \%$ of the prevailing patterns of dialogue in sample households.

- there were statistically significant differences in the patterns of dialogue prevalent among families sample depending on variables socio-economic level, were patterns of positive dialogue prevalent in families with volume at least the level of education of the parents high, while the patterns of dialogue negative followed in families large and with educational levels of parents low where the values are statistically significant at $0.5,0.01$, while there are no differences in the patterns of dialogue prisoners (positive and negative) prevailing in the sample households depending on variable monthly income.

- there were statistically significant differences between the members of the research sample aspects of self-management was in favor of the higher age and stage in favor of the study process, while there are no differences in the aspects of self-management between boys and girls in the research sample.

- There is a positive correlation between the aspects of self-management and positive dialogue patterns at a significance level of $(0.01,0.05)$, while there is a negative correlation between the aspects of self-management as the dependent variable and the negative patterns of dialogue at the level of significance $(0.05,0.01)$.

- vary the proportion of post independent variables studied (dialogue patterns prisoners, variables social and economic level) in the interpretation of the contrast ratio of the variable in terms of self-management was the most explanation the dialogue Anakashy divergence followed by the educational level of Parents Dialogue and was the least aggressive dialogue.

The researchers suggested a pilot program to educate young people basic of management dialogue prisoners.
\end{abstract}




\title{
أنهاط الحوار الأسرى وعلاقتها بإدارة الذات لدى الأبناء
}

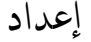

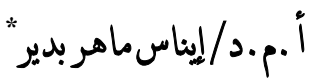 \\ أ.م.د ـ/رشاعبد العاطرراغت \\ مقدمة مشكلة البمث:
}

يعيث الإنسان اليوم ظروفا حياتية غاية فى التعقيد، حيث أصبح التغير السريع والمتلاحق

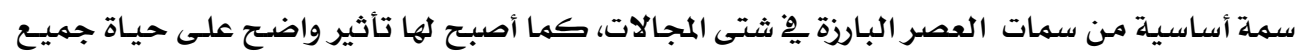

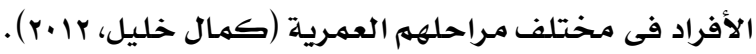

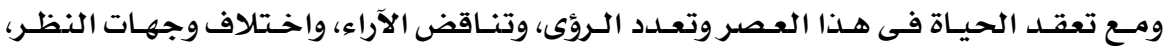

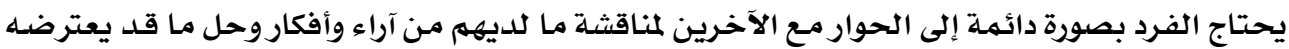

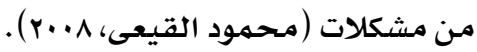

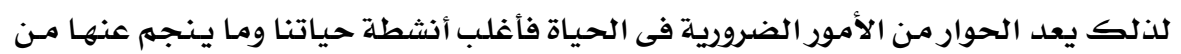

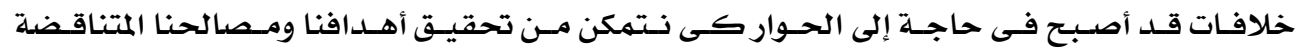

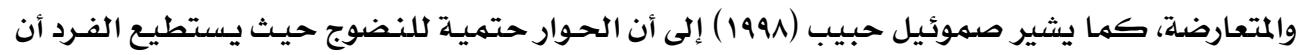

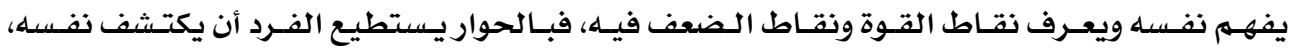
وقدراته، ويكتشف الآخرين ويستزد علما ويزيد إدراكه لذاته.

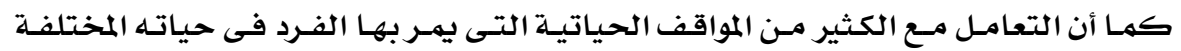

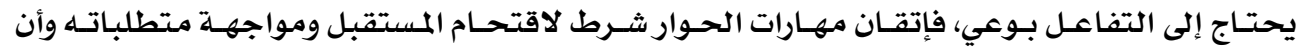

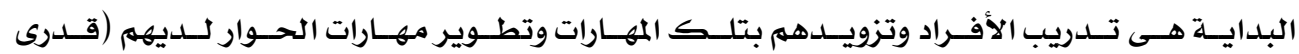
حنفى، (r... (r).

والحوار مـن أهم أسس الحياة الاجتماعية وضـرورة مـن ضـروراتها فهى إحـدى وسـائل الإنسـان

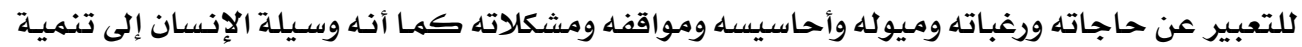

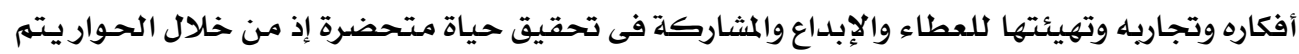

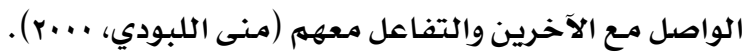

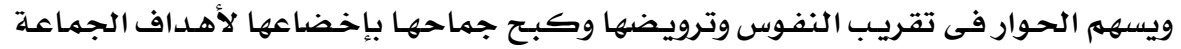

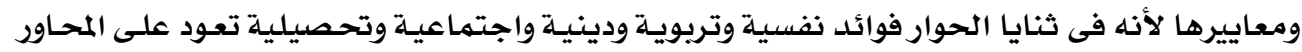

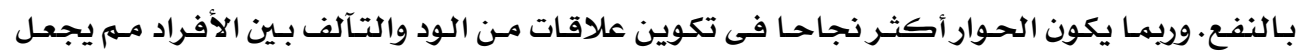

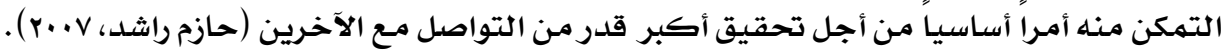

* الأستاذ المسساعد بقسه إدارة مؤسسات الأسرة والطفولة كلية الاقتصاد المنزلي - جامعة حلوان 
وبها أن الأسرة هى المؤسسة الأولى والأسـاسية المسئولة عن إعداد الشاب للدخول فى الحيـاة

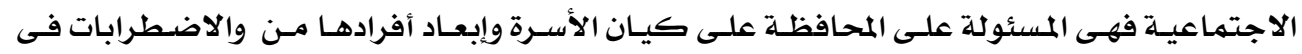

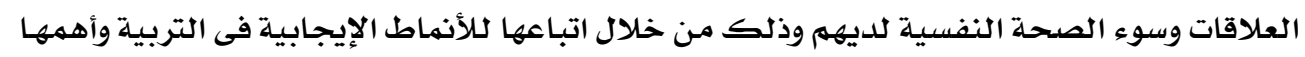

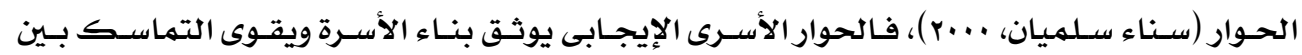

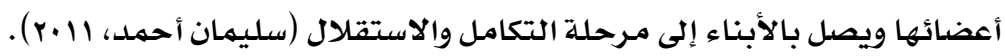

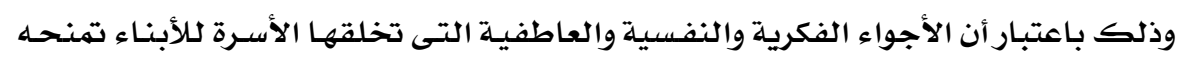

القدرة على التكيف الجدى مـع نفسه ومـع أسرته و مجتمعه (Bela \& Patrick, 2005).

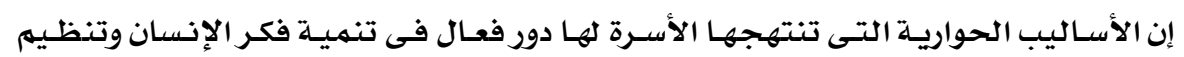

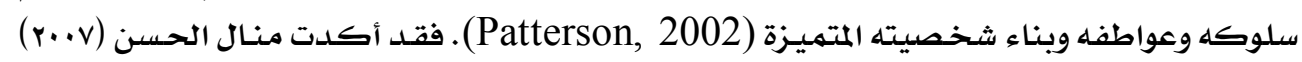

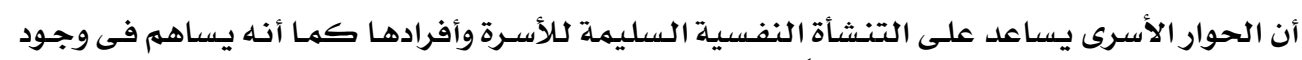

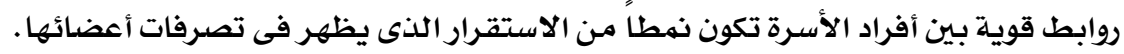

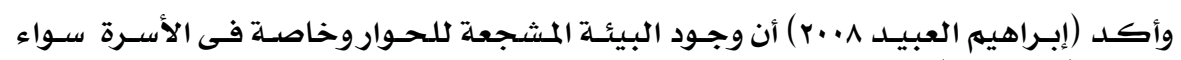

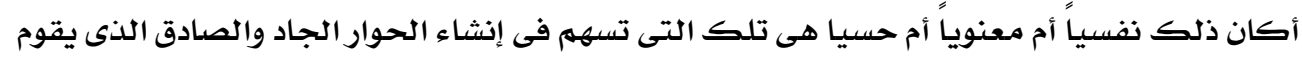

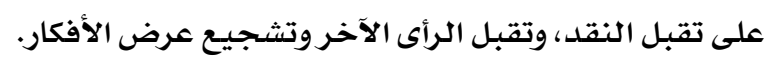

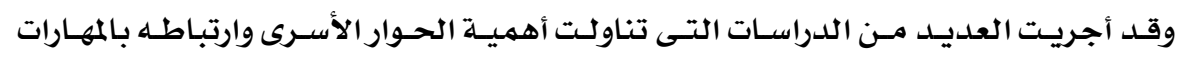

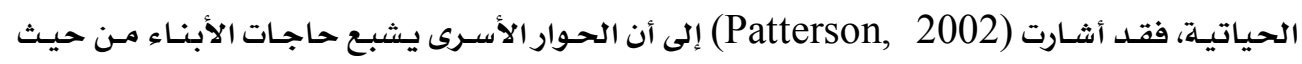
الشعور بالرضا والمصلحة المشتركة والذئى يقود في النهاية إلى النجاح والإنجار.

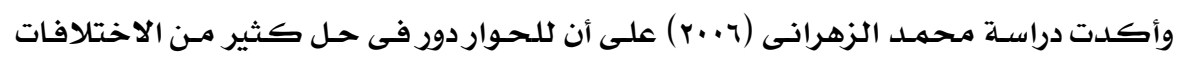

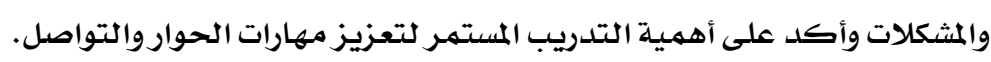

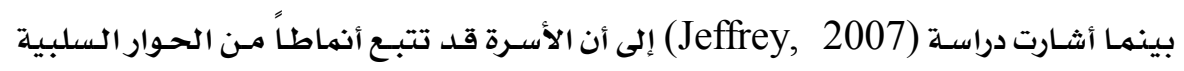
التى قد تهدد كيان الأسرة وتؤثر على الحالة النفسية لأبنائها .

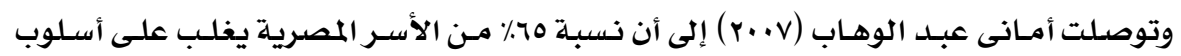

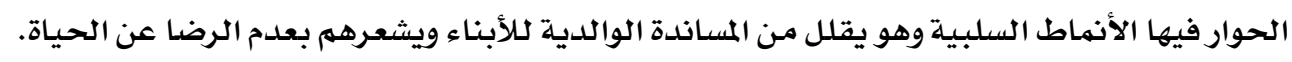

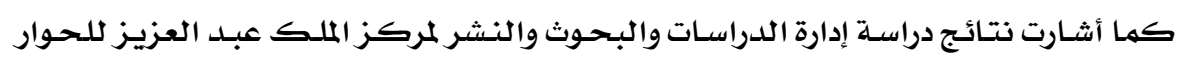

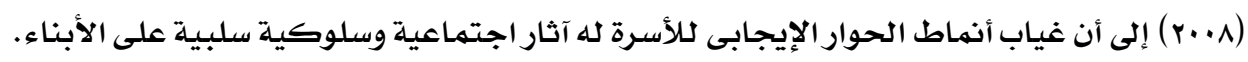

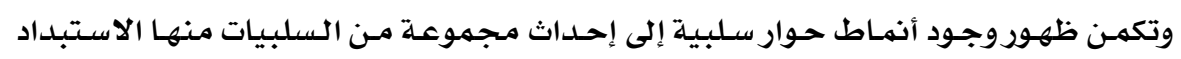

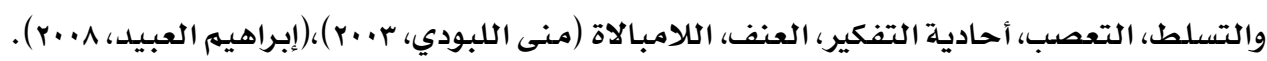

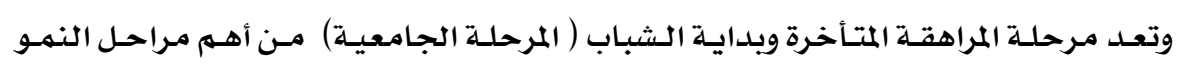

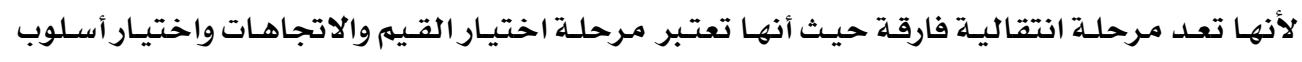

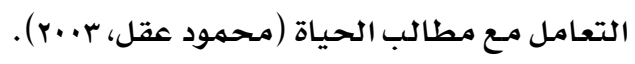




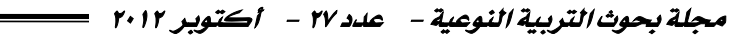

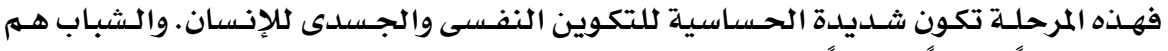

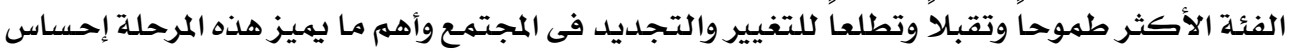
المراهق أو الشاب بذاته.

فالـذات عنـصـرا أسـاسـياً فـى تكوين الشخـصية وهـو مـا يتعلق عـادة بتصور الفـرد عـن نفســه والناتج عن خبر ات التفاعل مـع الأفراد الآخرين كما أن فهم الـذات وتحقيقها يعتبر الدافع الأسـاسىى الـذى يـدفع الإنسـان نحو العمـل والإنجـازوالإبـداع حيـث يعتبر دافـع تحقيـق الـذات قـوة رئيسيـة تـدفع الفرد لتطوير قدراته واستثمارها وتحقيقها (جابر عيسى، ربيع رثوان، ج +. ب ). ونجسـ أن مـصطلح إدارة الـذات مـن المصطلحات الحلديثة حيـث يـشهل على كلهـتين الأولى

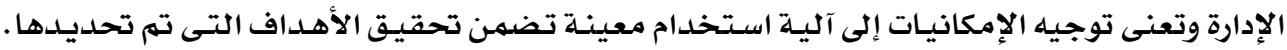

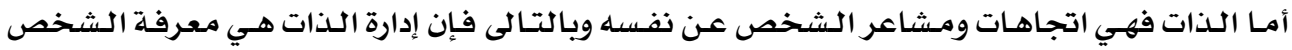

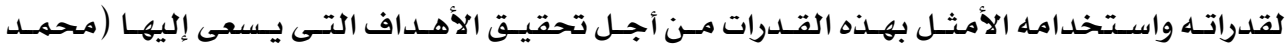

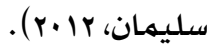

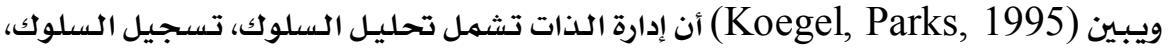

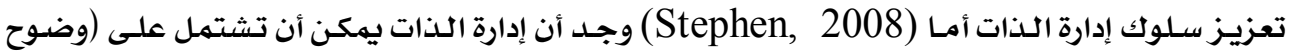

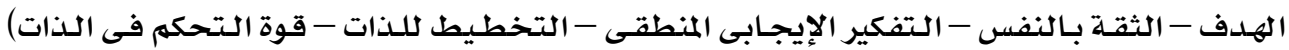

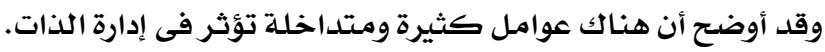

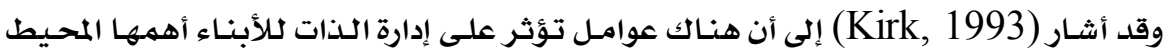

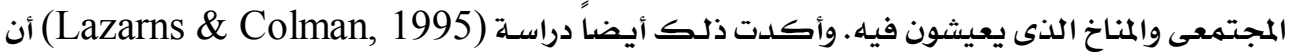

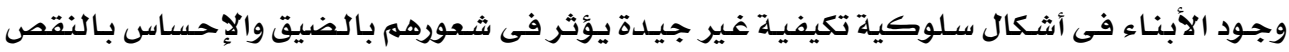
وعدم الكفاءة.

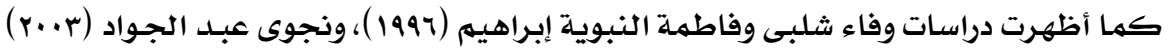

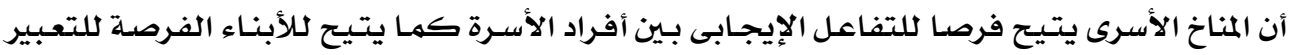

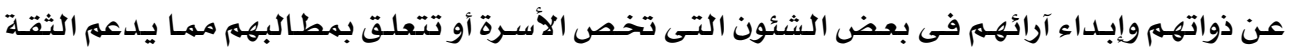
بالنفس ويبعث على الاستقلال والاعتمـاد على النفس. وقد أشـارت دراسـة (Eliot, 1993) (Richard \& Dollas, 1993) إلى وجـود علاقـة

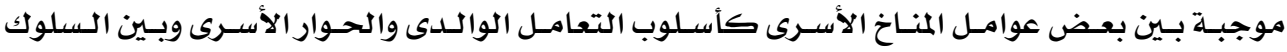

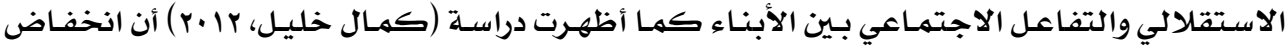

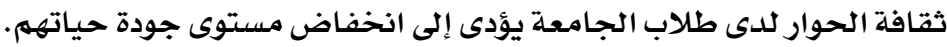
ومما سبق وجدت الباحثتان أهميـة دراسـة أنهـاط الحـوار الأسـرى الموجـودة في الأسـر المصرية

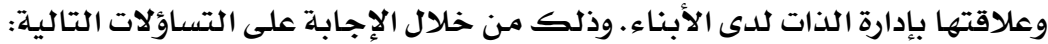

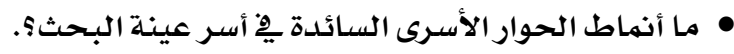




\section{• مـا جوانب إدارة الذات لدى الأبناء ِِّ عينة البحث؟.}

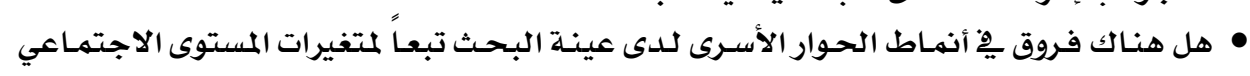

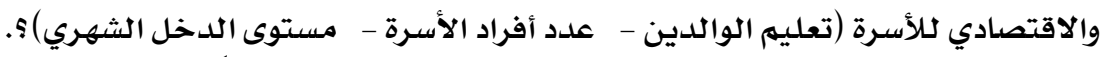

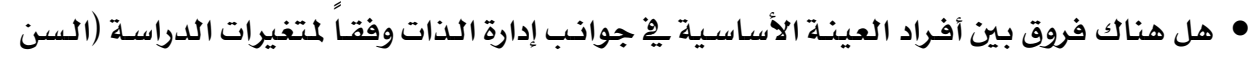

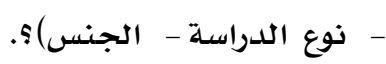

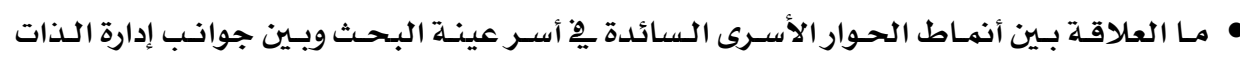

$$
\text { لدى الأبناء؟ }
$$

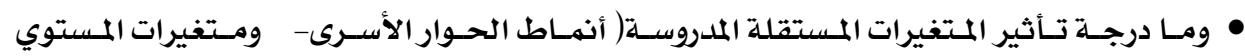
الاجتماعي والاقتصدادي) على جوانب إدارة الذات لـلأبناء؟.

يهاف البـحث الحالي التعرف على أنهاط الحوار الأسـرى وعلاقتها بـادارة الـذات لدى الأبنـاء

$$
\text { وذلك من خلال: 20 }
$$

ا . تحديد أنهاط الحوار الأسـرى السـائدة فى أسـر عينـة البحث.

r. الكثف عن جوانب إدارة الذات لدى الأبناء عينة البـحث.

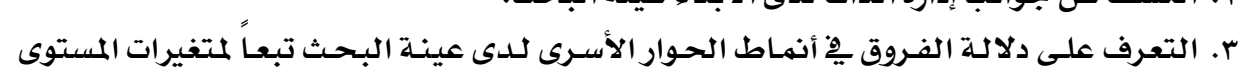

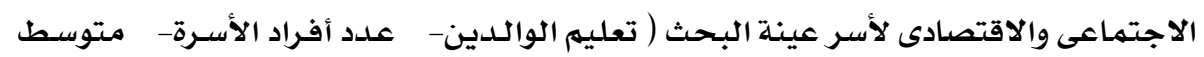

$$
\text { الدخل الشهري. }
$$

ع. التعرف على الفروق بـين أفراد عينـة البحث فى جوانب إدارة الذات وفقاً لمتغيرات الدراسة (السن

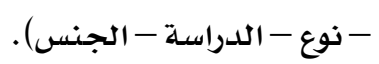

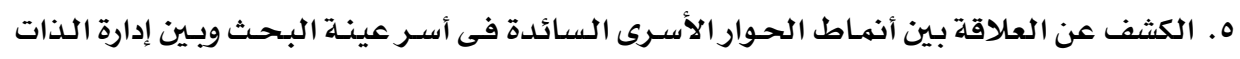

$$
\text { لدى الأبناء. }
$$

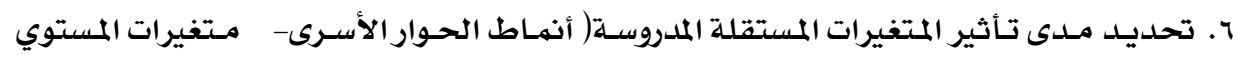
الاجتماعي والاقتصادي) على إدارة الذات لكلأبناء كمتغير تابع.

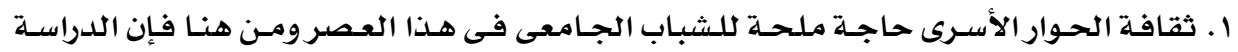

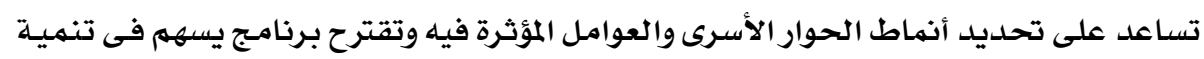

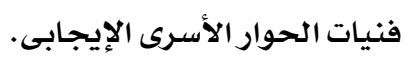

r. ندرة البـحوث العلميـة التي تتناول الحوار الأسـري للشبـاب حيـث أنـه لا توجـد دراسـة (فى حسلدود

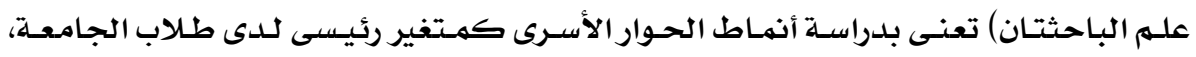
ومدى ارتباط هذا المتغير بإدارة الذات.

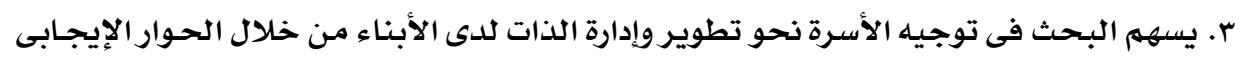
بأنماطه المختلفة. 


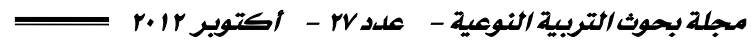

ع. يتتناول البـحث مرحلة عمـريـة هامـة وهى المرحلـة الجامعيـة لـا لها مـن أهميـة تتمثل فى الآمـال

المعلقة عليهم فى تنهية وتطوير المجتمـع.

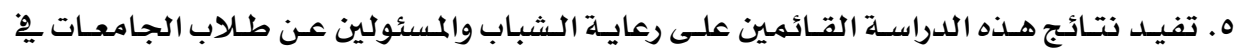
توجيهيهم وتوعيتهم وإرثـادهم وتنهمية فنيات الحـوار الإيجـابى لديهم وتعزيـز لغـة التفـاهم فى

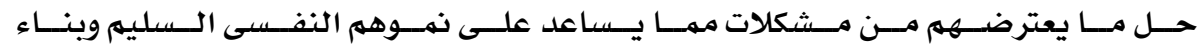
جوانب شخصياتههم.

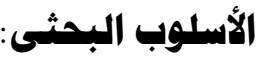

أولاً: فروض البحث:

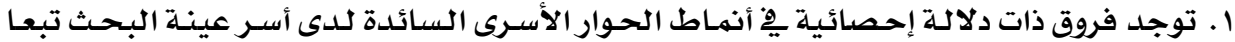

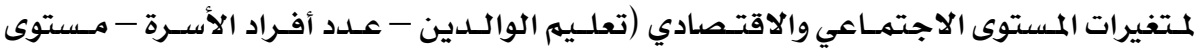

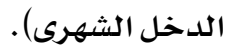

r. توجد فروق ذات دلالة إحصائية بين أفراد عينة البحث جوانب إدارة الذات وفقا لمتغيرات الدراسـة

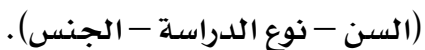

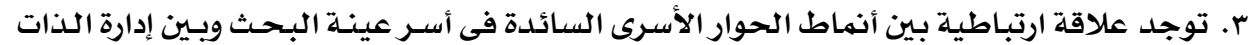

$$
\text { للدى الأبناء. }
$$

ع. توجد فروق يِ نسبـة مشاركة المتغيرات المستقلة المدروسـة (أنهاط الحـوار الإيجـابى) [التبـادلي -

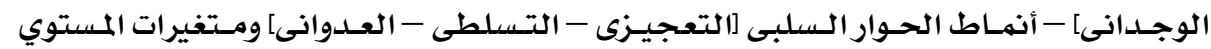
الاجتهـاعي والاقتصـادي فى المتغير التـابع (جوانب إدارة الـذات) تبعـا لأوزان معـاملات الانحسدار

ودرجة الارتباط.

\section{ثانياً: المفاهيه والمصطلحات البحثية:}

\section{•}

هـو سـلوك الفـرد المتكـرر لفـترة طويلـة مـن الزمـن كهـا يـراه الآخـرون ويعهـل الفـرد بهوجبـهـ ويعتبره الإطـار العـام الـذى يحـدد علاقاتـه مـع الآخـرين. والفـرد يتخــ نهطا معينـا مـن خـلال الخـبرة والتعليه والتدريب أو من الطفولة وقد يكون للفرد نهط غالب وهو الطابع العام المميز لشخصية الفـرد (سيد الهوارى، (1997) ).

وتعـرف إيهـان أحمـد (199V) الـنمط على أنه سـلوك متتكرر يعـبر عن شخهصية الفـرد، كهـا يعرفه راميل دور كايهم على أنه "طريقة أو نهوذج للسلوك أو هو نموذج للتفكير والعمل فى جماعـة مـن الجماعات (منى عبد الوارث، ع +. r) وقد يكون لكلأسـرة عدة أنهاط ولكن هنـاك نهـ غالـب وهـو الطـابع العام لها. 
• الحوار:

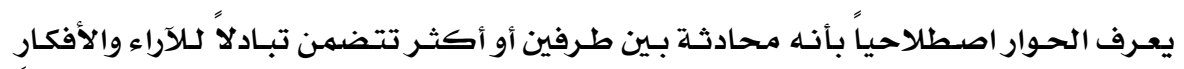

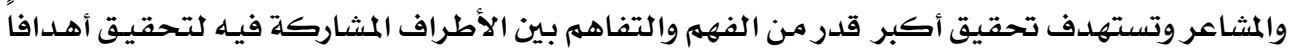

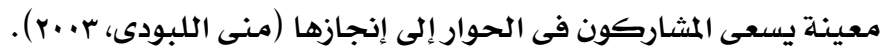
وهو أحد أثكال التواصل الشفوى التى تتضمن تبـادل الحسديث بـين فردين أو أكثر بطريقـة

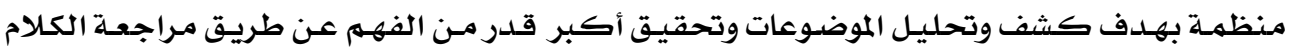

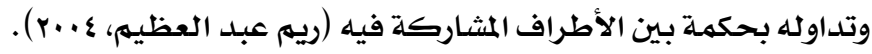

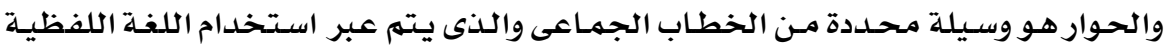

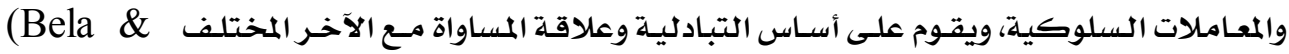
.Patrick, 2005)

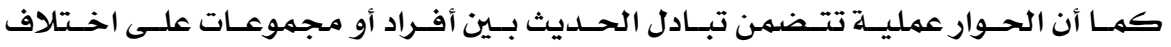

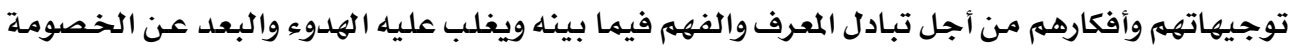

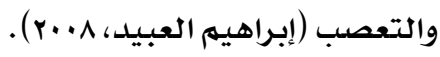
وهو القدرة على التفاعل المعرفى والعـاطفى والسلوكى مـع الآخرين وهو مـا يميز الإنسان

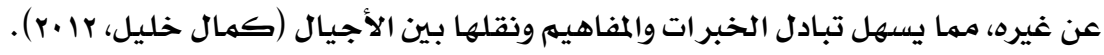
• (1الحوار الأسرى: هو التفاعل بين أفراد الأسرة الواحدة عن طريق المناقشة والحديث عن كل مـا يتعلق بشئون

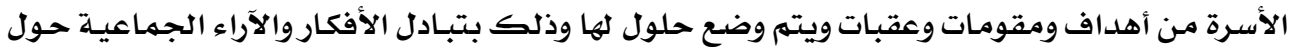

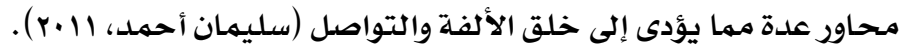
كما يعرف بأنه فن وعلم له أسسله وقواعده وهو الحوار الذى يلدور بـين أفراد الأسـرة يعيشون

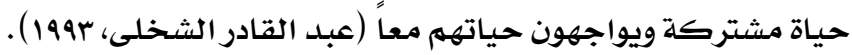

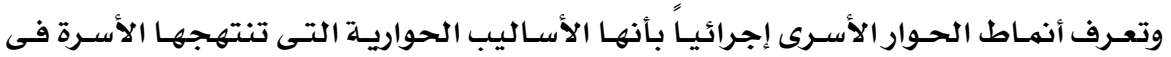

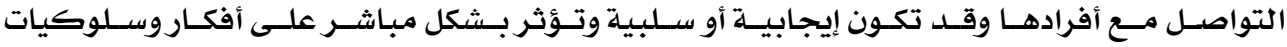
وشخصية أعضائها. • أنماط الحوار الأسرى: أولاً: الحوار الإيجابى:

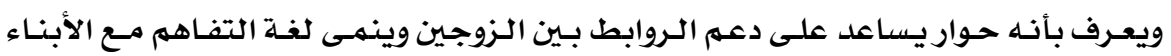

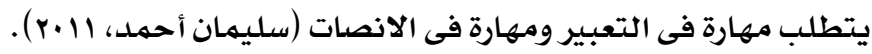




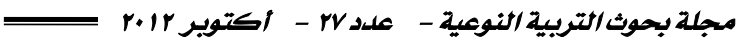

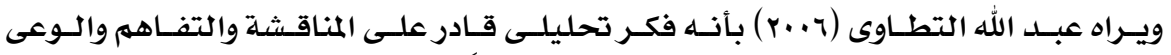

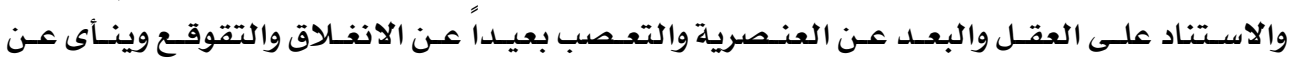

الاستعلاء والاستخفاف بمنظومة الآخرين.

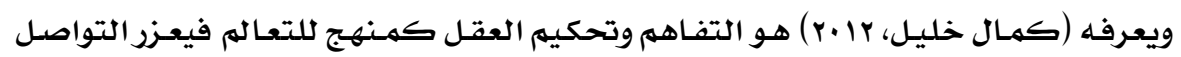

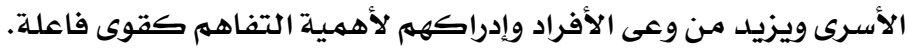

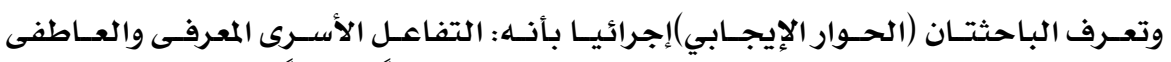

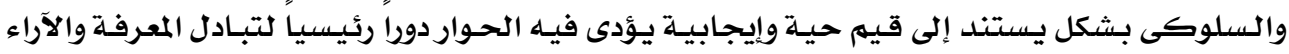

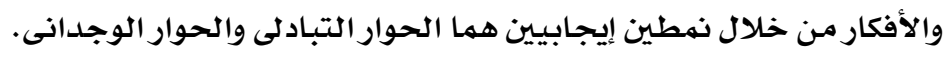

أنواع الحوار الإيجابى:

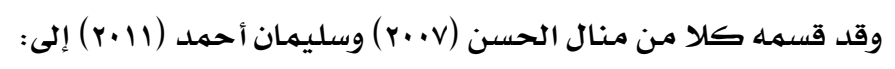

ا. الحوار النقاشى: وهو إما مواجهة أو مكتوب وهو أكثر الأسـاليب التى يتم من خـلال الحسوار بـين

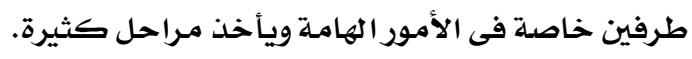

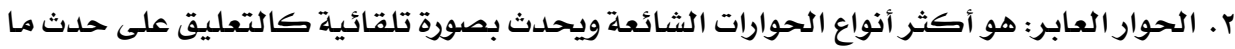

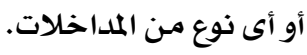

r. الحوار عن طريق العيون: وهى وسيلة للتعبير عن كثير من الكـلام فنظرات الإنسان وحركاتـه

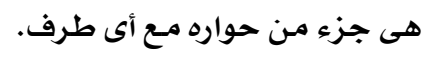

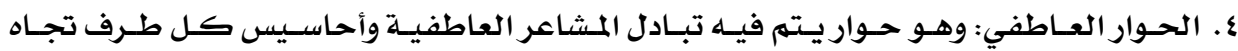

$$
\text { الطرف الآخر. }
$$

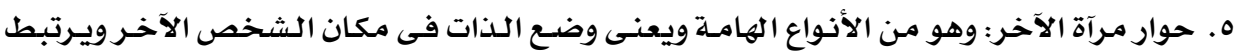

$$
\text { بمدى الرضا عن الطرف الآخر. }
$$

وقد رأت الباحثتان تقسيم الحوار الإيجابي إلى نهطين رئيسيين هما :

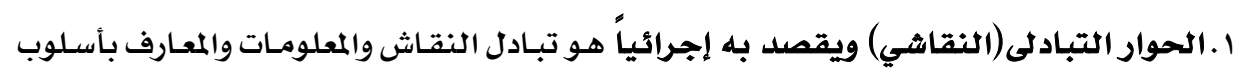

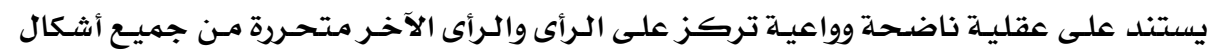

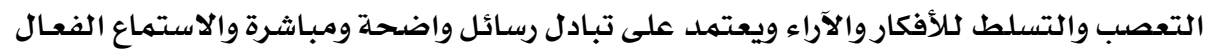

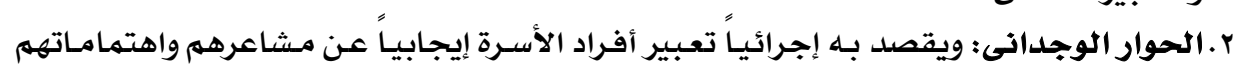

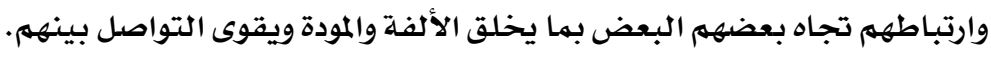

$$
\text { ثانياً: الحوار السلبى: }
$$

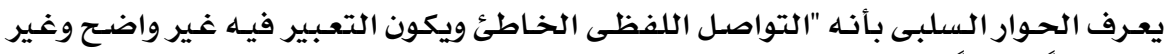

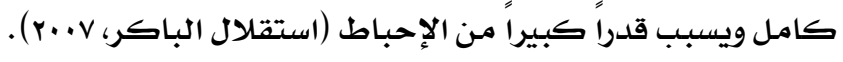


وتعرف الباحثتان الحوار السلبي إجرائيـاً: هو التفاعل اللفظى اللالايجـابى بـين أفراد الأسـرة

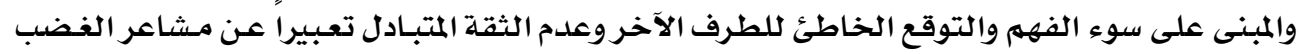

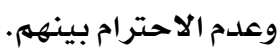

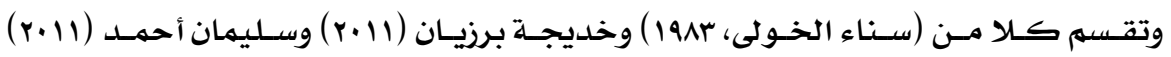
الحوار السلبى إلى:

ا. الحوار التعجيزى: وفيه لا يرى أحد طرفى الحوار أو كلاهمها إلا السلبيات والأخطاء والعقبـات

$$
\text { وينتهى الحوار إلى أنه لا فائدة. }
$$

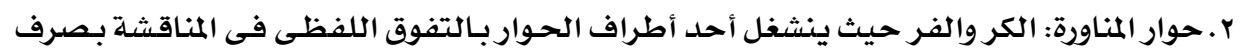

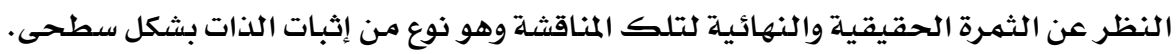

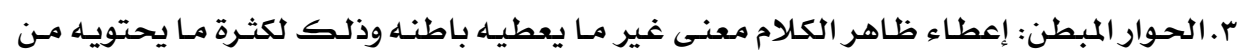

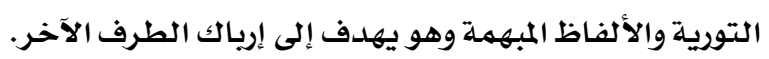

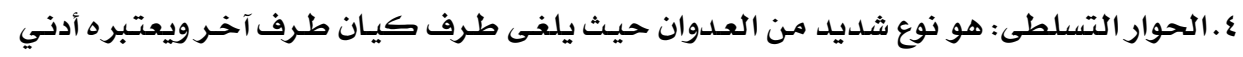

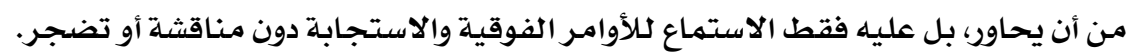

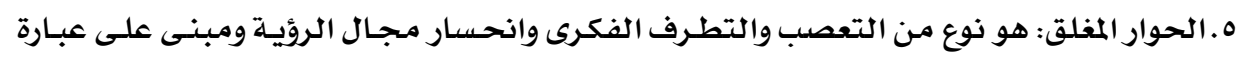

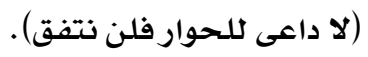

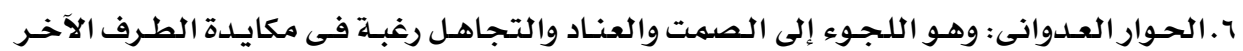

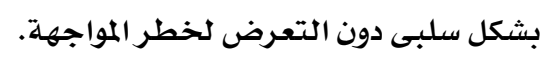

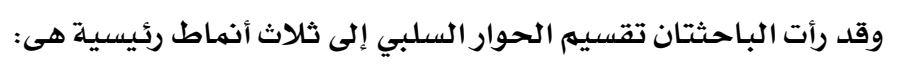

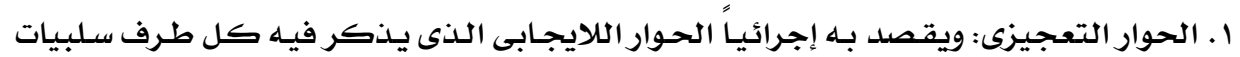

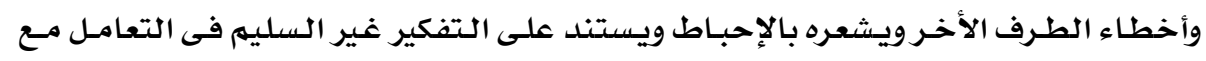

$$
\text { الآخرين والرؤى الخاطئة عن الآخر. }
$$

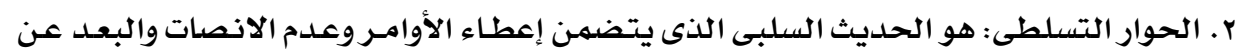

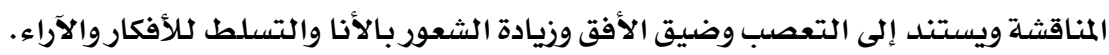

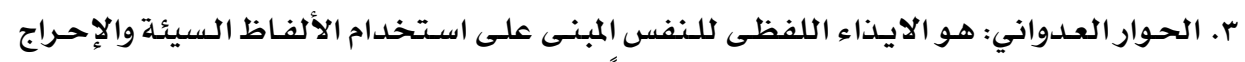

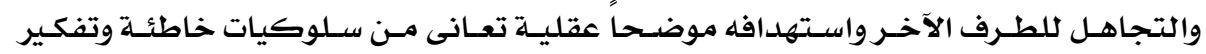

$$
\text { غير متزن. }
$$

\section{مفاهيه إدارة السذات: - ميرن}

$$
\text { • مفهوم الذات: }
$$

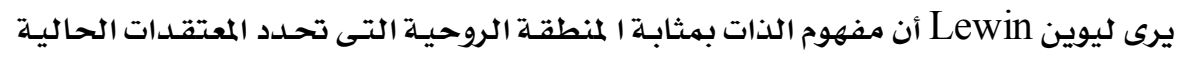

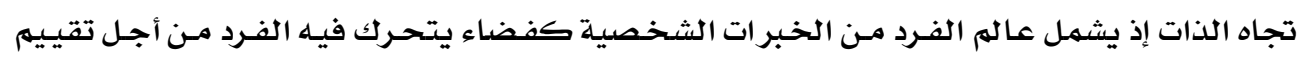

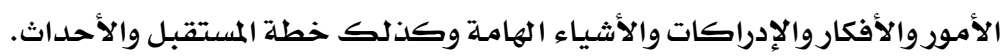




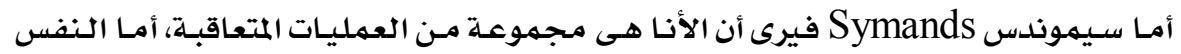

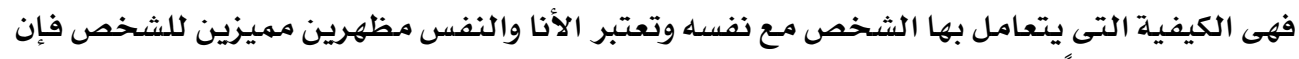

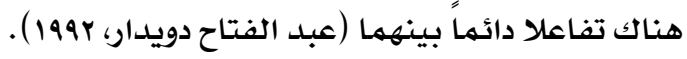

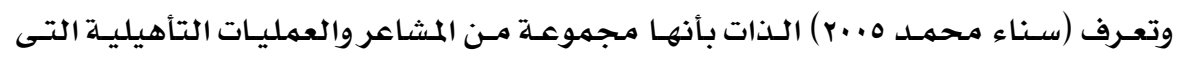

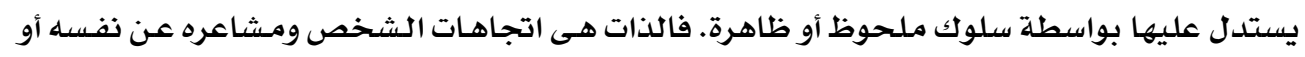

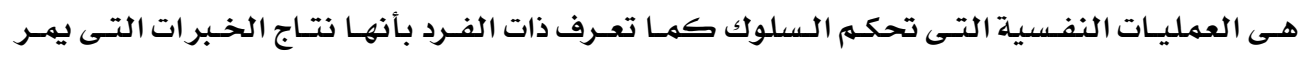
بها الشخص.

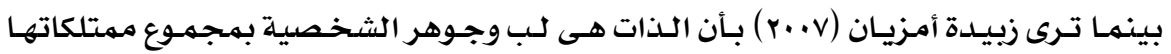

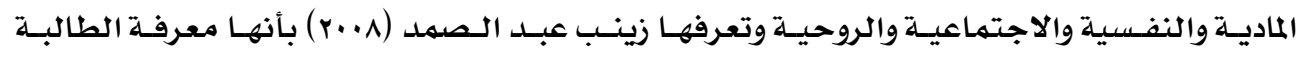

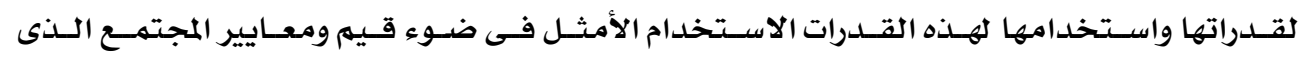
يعيث فيه. • يعرف (Koegel et al \& Parts, 1995) إدارة الذات بأنها عبارة عن إجراء يتهم فيـه تعليه

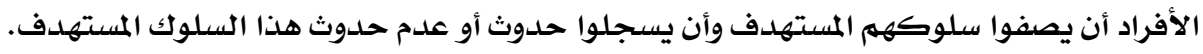

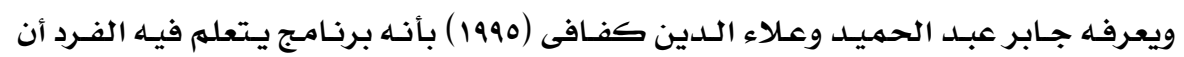

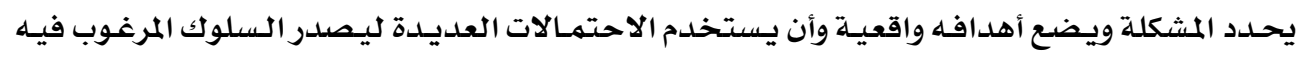

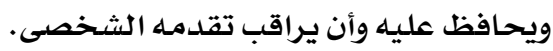

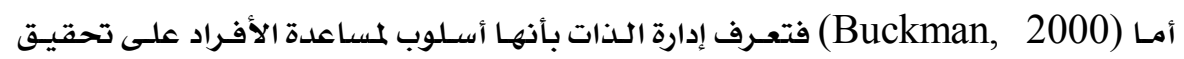

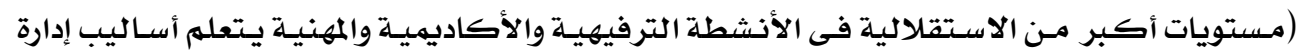

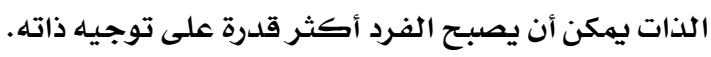

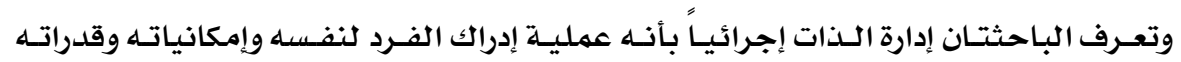

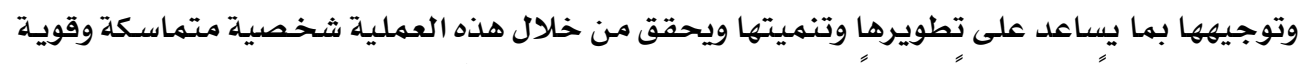

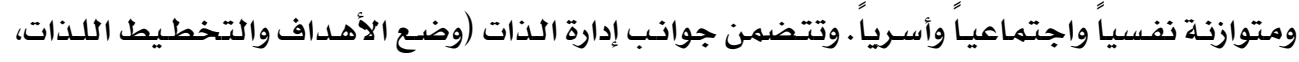

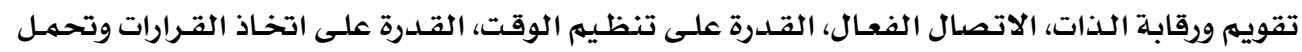

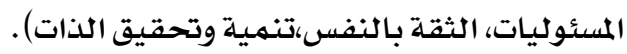

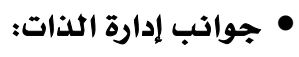

ا. وضع الأهداف والتخطيط للذات وتعرف إجرائياً بأنها إدراك الفرد لذاته ورسهم المسار المناسب

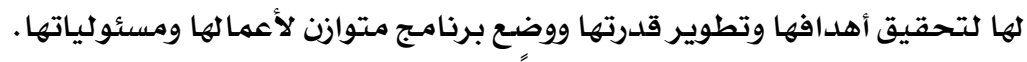

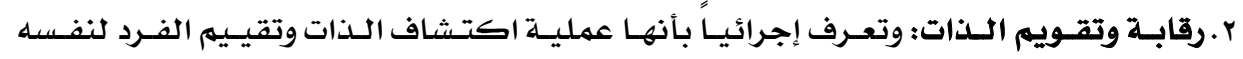
واكتشاف نقاط القوة والضعف فى شخصيته وتصحيح وتعديل السلبيات وتعزيز الايجابيات. 


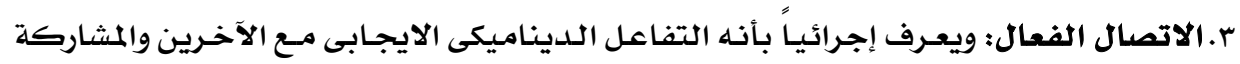

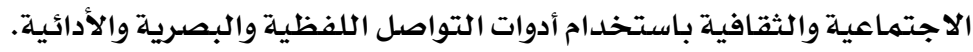

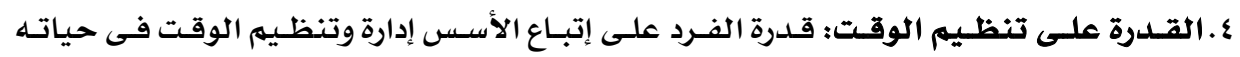

الدراسية والأسـرية.

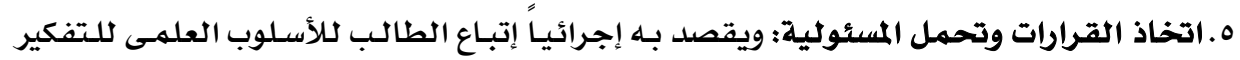

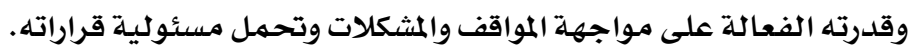

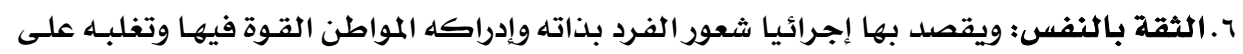

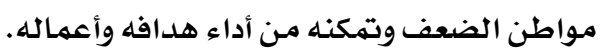

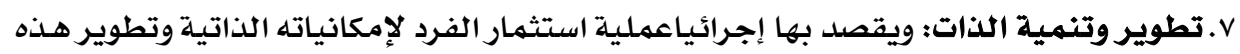

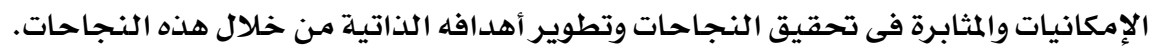

ثالثًا: منهج البحث:

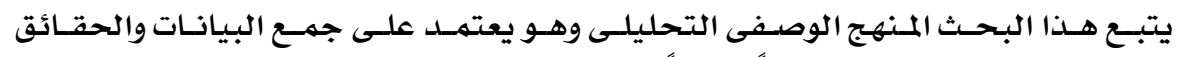

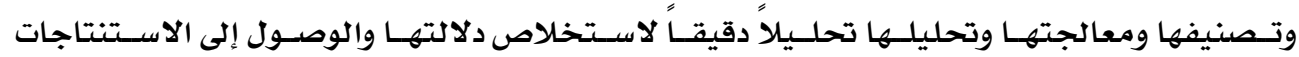

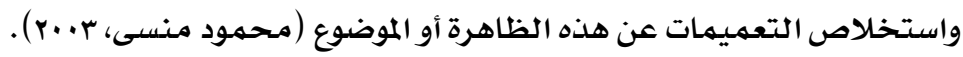

رابعاً: حلدود البحث:

ا ـ عينـة البحث الاستطلاعية: تكونت مـن (10) طالب وطالبـة في المرحلـة الجامعيـة وتقـع مـا بـين

عام وتم اختيارهن بطريقة مشروطة من المنتميين لأسر متكاملة الأركان (أب و وأمو و

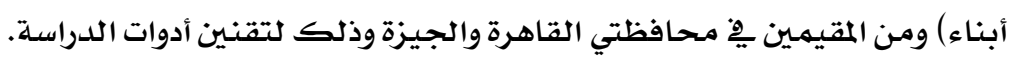

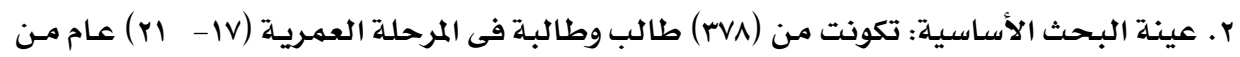

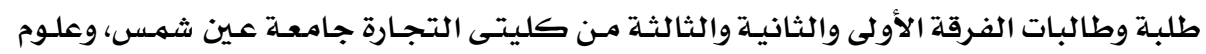

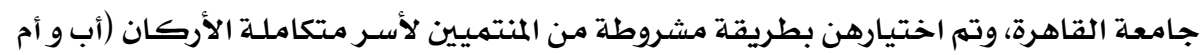

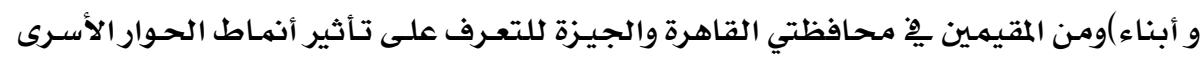

$$
\text { في هذه الأسر على إدارة الدات. }
$$

خامساً: أدوات البحث: ت فئه

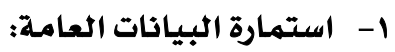

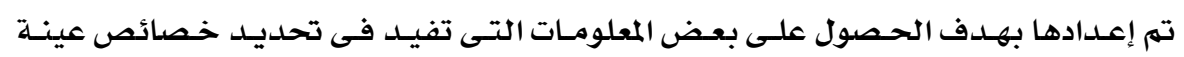

$$
\text { البحث واشتملت هذه الدراسـة على: }
$$

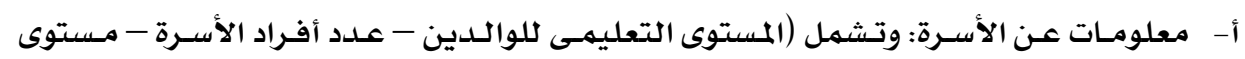

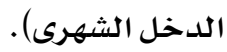

ب- معلومات عن الأبناء: وتشمل (السن - الجنس - نوع الدراسـة). 
r- مقياس أنماط الحوار الأسرى (إعداد الباحثتان):

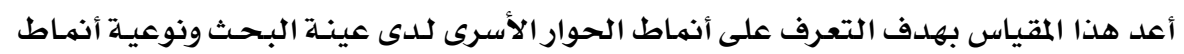

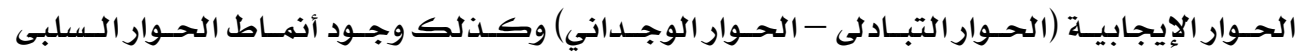

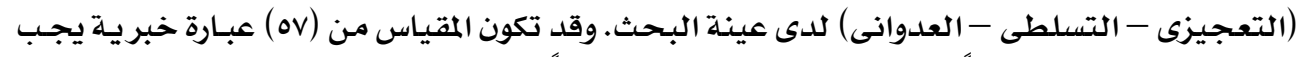

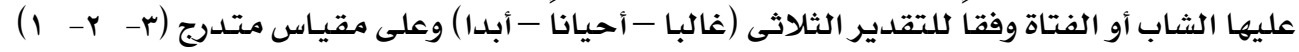

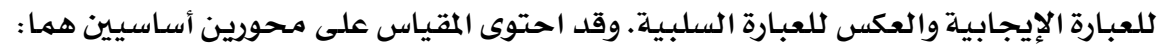
ا. الحوار الإيجابى وقد أخذت عبارات هذا المحور الاتجاه الإيجابى

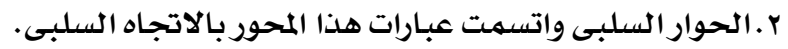
وتكون الحوار الإيجابى من محورين هما:

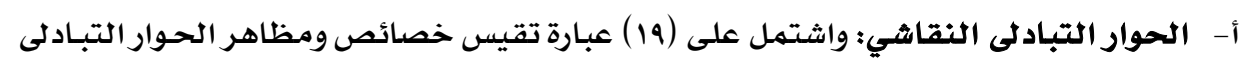

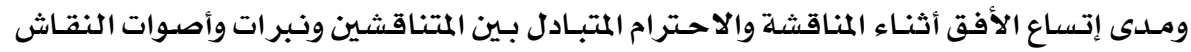

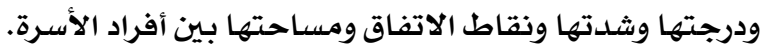

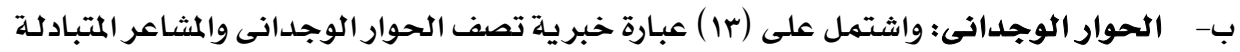

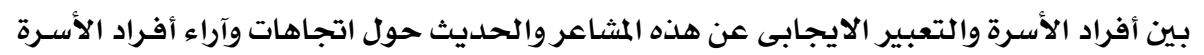

$$
\text { نحو بعضهم البعض. }
$$

$$
\text { أما الحوار السلبى فيتكون من ثلاث محاور هي: }
$$

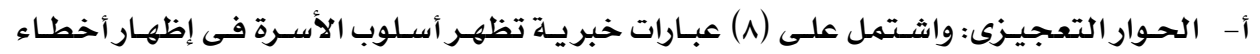

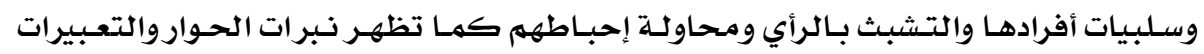
المصاحبة لهذا النوع من الحوار.

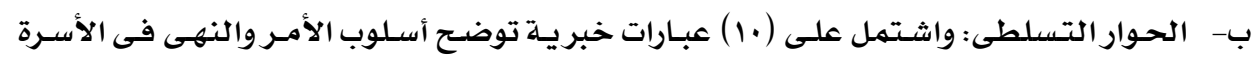

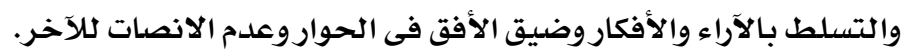

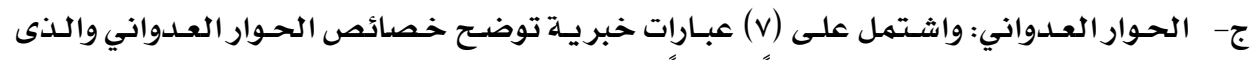

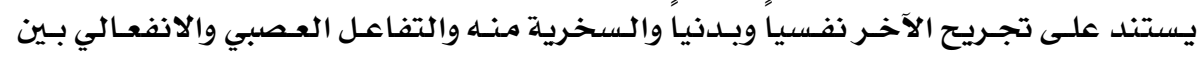
أفراد الأسرة. r- مقياس إدارة الذات لدى الأنباء (إعداد الباحثتان):

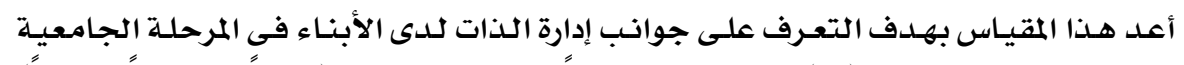

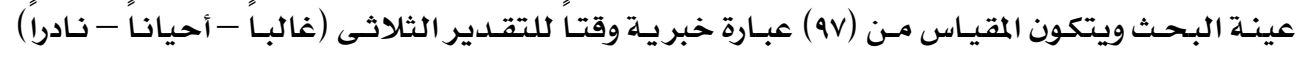

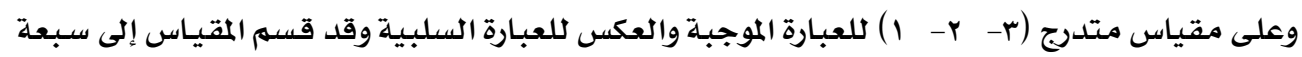
محاور هى: أ- المحور الأول: وضع الأهداف والتخطيط للذات: واشتمل على (عات ) عبارة تقيس قدرة الطالب

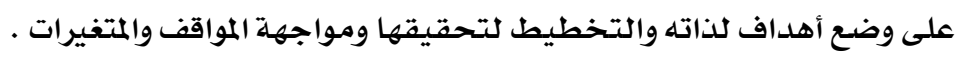


ب- المحور الثانى: تقويهم ورقابة الذات: ويحتوى على (ه) عبـارة تقيس قدرة الأبنـاء على توجيـه

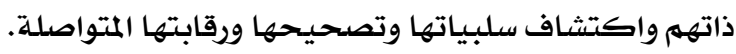

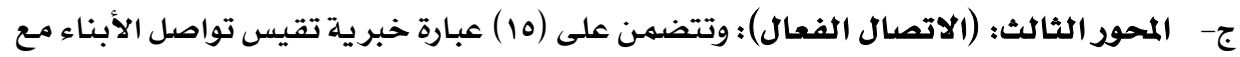

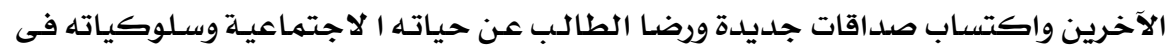
مهارسسة علاقتته مـع الآخرين.

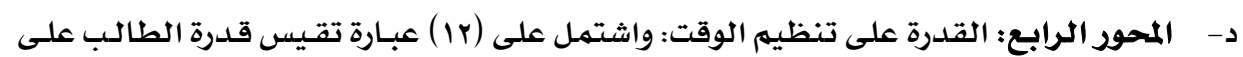

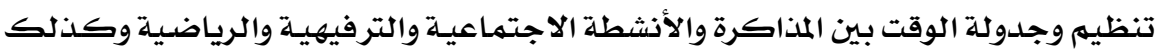

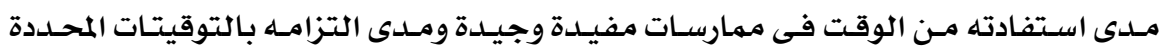
كلأعمال المختلفة.

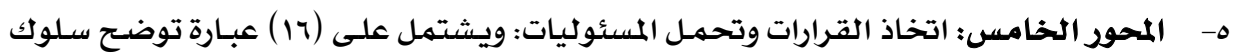

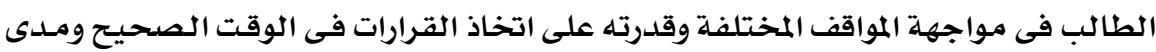

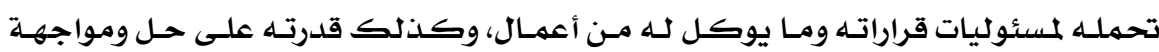
المشكلات التى قد يتعرض لها.

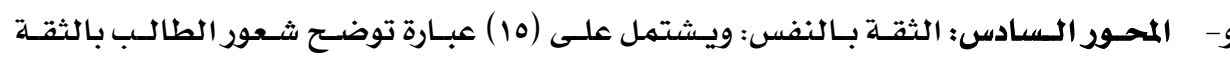

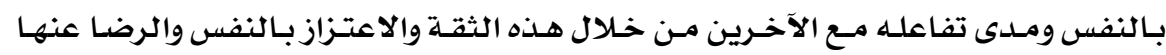

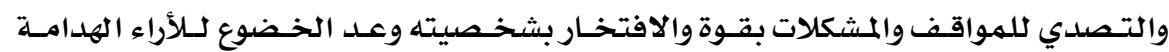

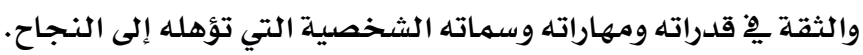

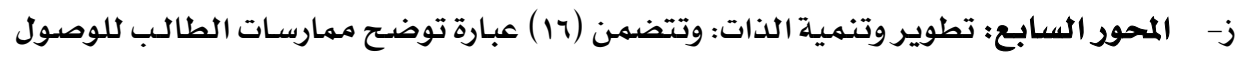

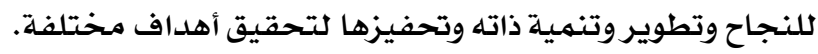

: الأدوات:

يقصد بـ قياس صدق وثبات المقاييس: أولاً: صدق المقاييس:

اعتمدت الباحثتان فى ذلك على كل من:

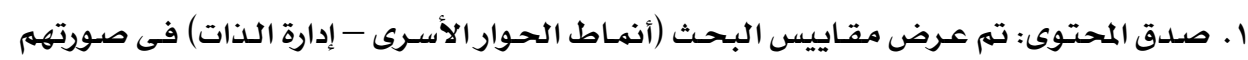

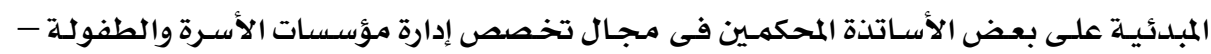

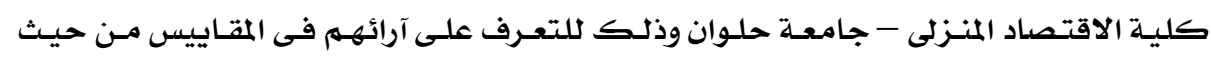

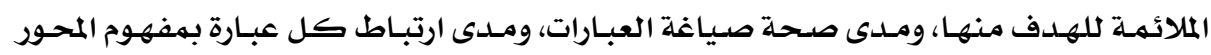

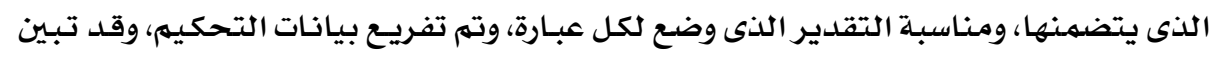

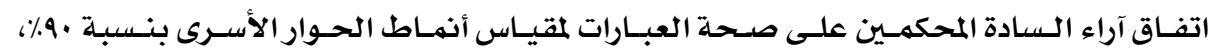

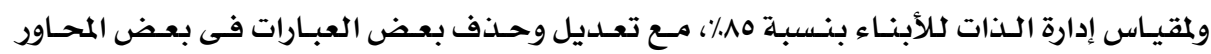
وقامت الباحثتان بالتعديلات المشار إليها. 


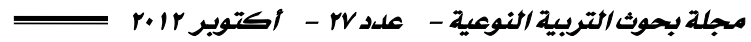

r. الاتسـاق الداخلى: وذلك بحسـاب معامل ارتباط بيرسون بين محاور المقياس والمجمهوع الكلى لـهـ

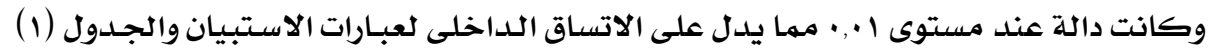

$$
\text { يوضح ذلك. }
$$

جدول (1) صدق الاتسـاق الداخلى لأدوات الدراسـة باستخدام معامل بيرسون

\begin{tabular}{|c|c|c|}
\hline مستوى الدلالة & معامل ارتباط بيرسون & قياس أنماط الحوار الأسرى \\
\hline$\cdot, \cdot 1$ & $\cdot, 9 \varepsilon$ & المحور الأول: الحوار الإيجابى \\
\hline$\cdot, \cdot 1$ & $\cdot, 109$ & أ- الحوار التبادلى \\
\hline$\cdot, \cdot 1$ & $\cdot$ VAT & ب- الحوار الوجدانى \\
\hline$\cdot, \cdot 1$ & $\cdot 91 \mathrm{r}$ & المحور الثانى: الحوار السلبى \\
\hline$\cdot, \cdot 1$ & $\cdot$, nor & أ- الحوار التعجيزى \\
\hline$\cdot, \cdot 1$ & $\cdot, 9 r \varepsilon$ & ب- الحوار التسلطى \\
\hline., .1 & $\cdot, \wedge 90$ & ج- الحوار العدواني \\
\hline مستوى الدلالة & معامل الارتباط & مقياس إدارة الذات الأبناء \\
\hline$\cdot, \cdot 1$ & $\cdot \wedge \mu \mathrm{V}$ & 1- وضع الأهداف والتخطيط للذات \\
\hline$\cdot, \cdot 1$ & $\cdot, 109$ & 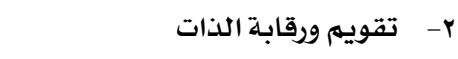 \\
\hline$\cdot, \cdot 1$ & $\cdot, \wedge \vee 1$ & بـ- الاتصال الفعال \\
\hline$\cdot, \cdot 1$ & $\cdot, 919$ & ع- القدرة على تنظيم الوقت \\
\hline$\cdot, 1$ & $\cdot, 911$ & هـ اتخاذ القرارات وتحمل المسئوليات \\
\hline$\cdot, \cdot 1$ & $\cdot, 9 \leqslant \varepsilon$ & آ- الثقة بالنفس \\
\hline$\cdot, \cdot 1$ & .941 & v- تطوير وتنمية الدات \\
\hline
\end{tabular}

\section{ثانياً: حساب ثبات المقاييس:}

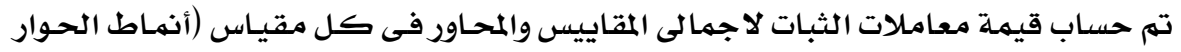

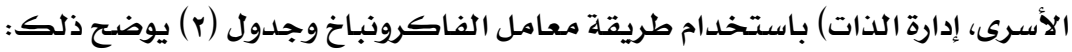


جدول (r) الثبات بطريقة الفاكرونباخ لأدوات الدراسة

\begin{tabular}{|c|c|c|}
\hline معامل الفاكرونباخ & عدد العبارات & مقياس أنهاط الحواروالأسـىى \\
\hline \multicolumn{3}{|r|}{ المحور الأول: الحوار الايجابى } \\
\hline$\cdot, \wedge \leqslant 1$ & 19 & أ- الحوار التبـادلى النقاشى \\
\hline$\cdot, \mathrm{Va} \cdot$ & ir & ب- الحوار الوجدانى \\
\hline \multicolumn{3}{|r|}{ المحور الثانى: والحوار السلبى } \\
\hline$\cdot, 9 \cdot 0$ & $\wedge$ & أ- الحوار التعجيزى \\
\hline$\cdot, \wedge 17$ & 1. & ب- الحوار التسلطى \\
\hline$\cdot, \wedge \cdot \varepsilon$ & $\checkmark$ & ج- الحوار العدوانى \\
\hline$\cdot, \wedge r q$ & ov & المقياس ككل \\
\hline معامل الفاكرونباخ & عدد العبارات & مقياس إدارة الذات \\
\hline$\cdot, \wedge r t$ & $1 \varepsilon$ & المحور الأول: وضع الأهداف والتخطيط للذات \\
\hline$\cdot, \Lambda \Lambda \varepsilon$ & 9 & المحور الثانى: تقوييم ورقابة الذات \\
\hline$\cdot 9 \mathrm{rr}$ & 10 & المحور الثالث: الاتصسال الفعال \\
\hline$\cdot, \Lambda \wedge T$ & ir & المحور الرابع: القدرة على تنظيهم الوقت \\
\hline$\cdot 90 \mathrm{r}$ & 17 & المحور الخامس: اتخاذ القرارات وتحمل المسئوليات \\
\hline$\cdot 94 \varepsilon$ & 10 & المححور السـادس: الثقة بـالنفس \\
\hline$\cdot$, var & 17 & المحور السـابع: تطوير وتنـميـة الذات \\
\hline., 91. & QV & المقياس ككل \\
\hline
\end{tabular}

يتضـح مـن جـدول (ץ) أن قيم معـاملات الثبـات للمقيـاس عاليـة مما يـدل على ثبـات المقيـاس وصلاحيته للتطبيق.

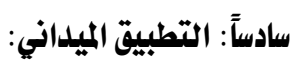
تم تطبيـق أدوات الدراســة علـي عينــة البـحـث الأسـاسـية ِِّ الفـترة مـن أول فبرايـر إلـي أول

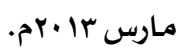
سابعاً: المعالجات الإحصائية: مانية

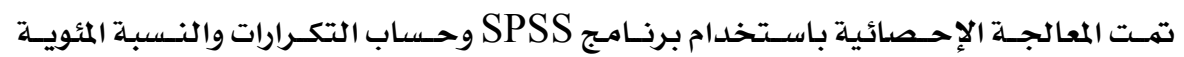

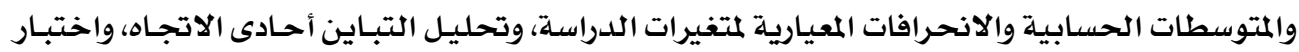

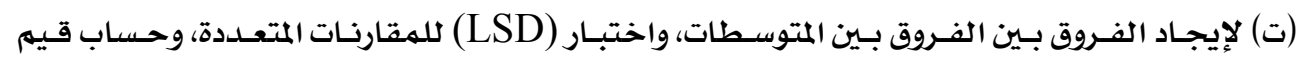
معاملات ارتباط بيرسون. 


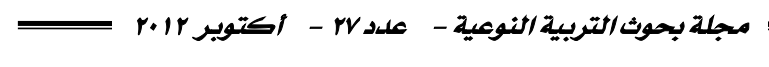

\section{نتائج البحث تصليلها وتفسيرها:

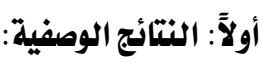

1- وصف العينة الأساسية من الأبناء: فيما يلى وصف شامل لعينة البحث موضحة فى جدول (r).

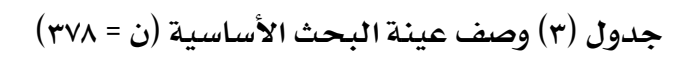

\begin{tabular}{|c|c|c|c|}
\hline النسبـة المئويـة & العدد ال العد & الفئـة & البيـان \\
\hline 00,70 & Yl. & من IV إلى أقل من 19 عام & 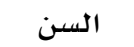 \\
\hline$\varepsilon \varepsilon, \varepsilon$ & 171 & من 19 إلى أقل من اY عام & \\
\hline $1 \cdots$ & rVA & الإجمالى & \\
\hline$\varepsilon \vee, q$ & $|\wedge|$ & بنين & الجنس \\
\hline or, 1 & $19 V$ & 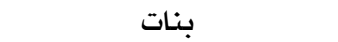 & \\
\hline $1 \cdots$ & rVA & الاجمالى & \\
\hline $7 \cdot, 1$ & rrV & كلية تجارة (دراسـة نظريـة) & التخصص \\
\hline rq,q & 101 & كلية العلوم (دراسـة عملية) & \\
\hline $1 \ldots$ & rVA & الإجمـالى & \\
\hline
\end{tabular}

$$
\text { يتضح من جدول (r) ما يلى: }
$$

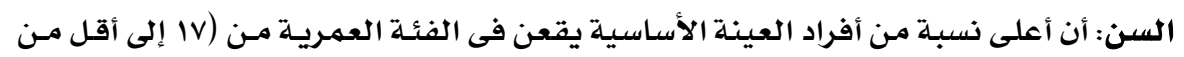

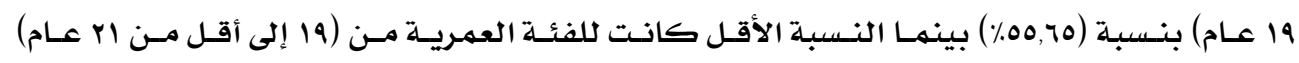

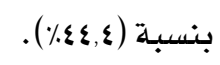

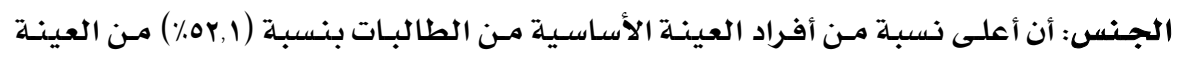

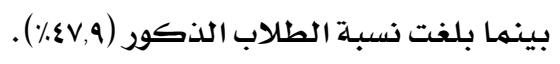

التخصص: أن غالبيـة أفراد العينـة الأسـاسية كانوا يدرسـن دراسـة نظريـة (كليـة التجـارة)

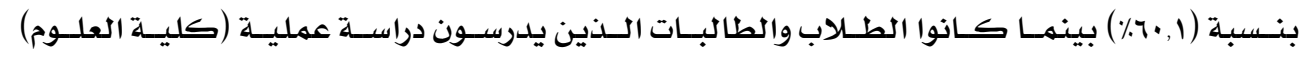

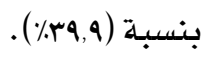


r - وصف متغيرات المستوى الاجتماعى والاقتصادى لأسـر عينة البـحث: PVA = جلدول (ع ) وصف متغيرات المستوى الاجتماعى والاقتصادى لأسر عينـة البحث ن

\begin{tabular}{|c|c|c|c|}
\hline النسببـة المئوية & العلدد & الفئـة & البيـان \\
\hline $11, r$ & $\varepsilon r$ & منخفض (تعليهم أسـاسى) & المستوى التعليمى للأب \\
\hline ro & Irr & متوسط (ثانوي وفوق متوسط) & \\
\hline or, $v$ & $r \cdot r$ & مـرتفـع (جـامعى وفوق جـامعى) & \\
\hline $1 \cdots$ & rV & الإجمالى & \\
\hline 11 & $\uparrow$ & منخفض (تعليم أسـاسى) & المستوى التعليمى لكلأم \\
\hline r. & $11 r$ & متوسط (ثانوي وفوق متوسط) & \\
\hline or & $19 \mathrm{~V}$ & مـرتفع (جامعى وفوق جامعى) & \\
\hline $1 \cdots$ & rvs & الإجمـالى & \\
\hline$r \varepsilon, T$ & ar & من r : ع أفراد & عدد أفراد الأسـرة \\
\hline vo, & Y^o & من 0 : أفراد & \\
\hline $1 \cdots$ & rvi & الإججمالى & \\
\hline rA. & 1.7 & منخفض (أقل من · م0 جنيه) & الدخل الشهرى للأسـرة \\
\hline$£ 0,0$ & IVY & 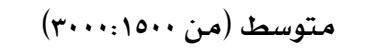 & \\
\hline rq, & $1 \cdots$ & مرتفع (أكثر من ... م) & \\
\hline $1 \cdots$ & rvi & الإجمالي & \\
\hline
\end{tabular}

$$
\text { يتضح من جدول (ع ) ما يلى: }
$$

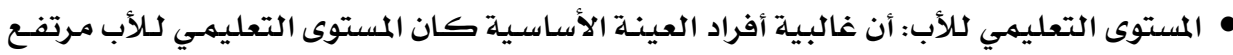

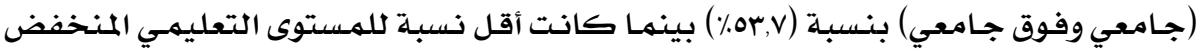

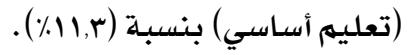

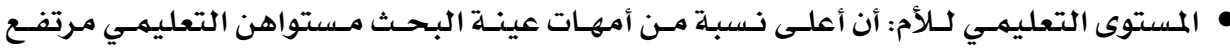

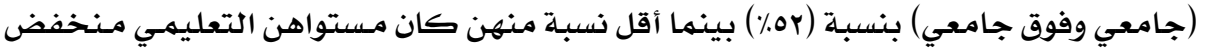

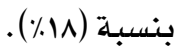

• عدد أفراد الأسـرة: غالبيـة أفراد العينـة الأسـاسية ينـتهـين لأسـر عدد أفرادهـا مـن (ه- ج أفراد )

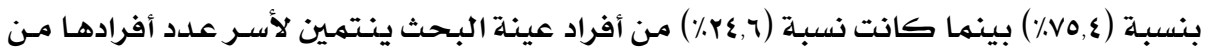

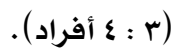

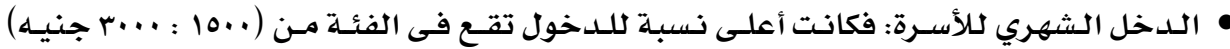

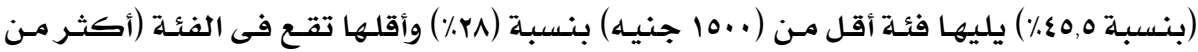

$$
\text { (r... }
$$




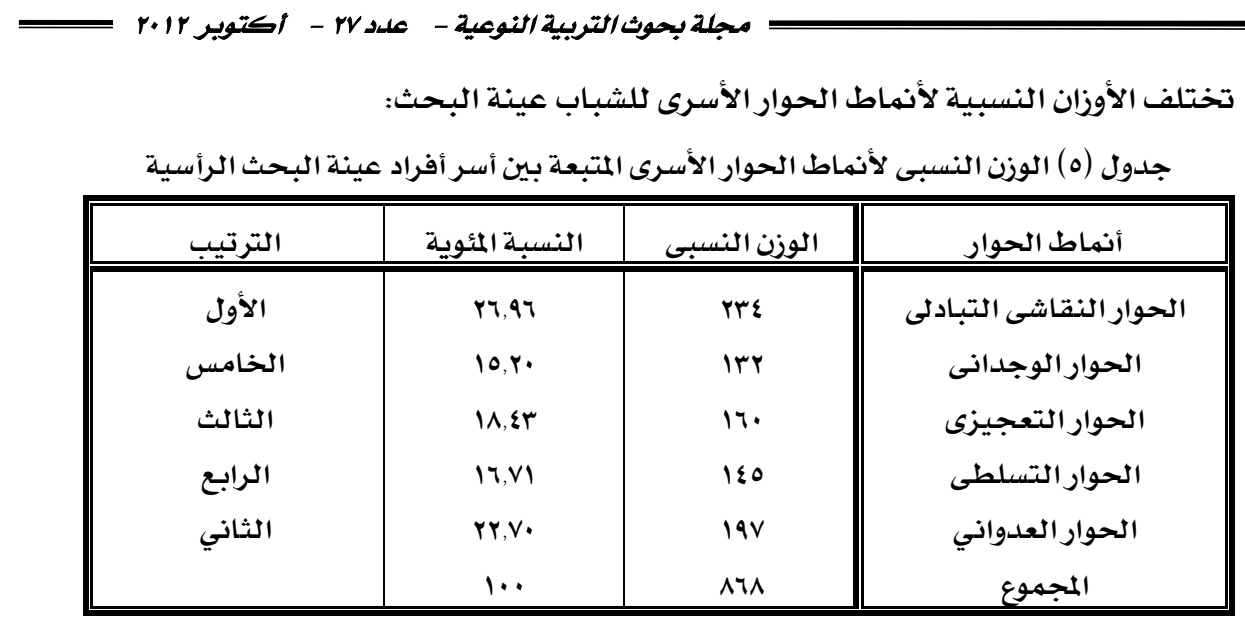

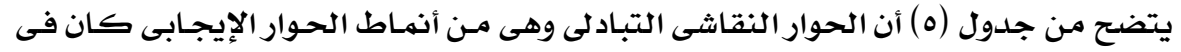

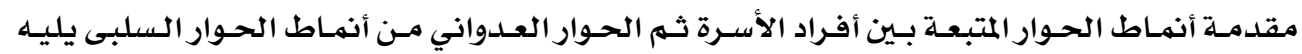

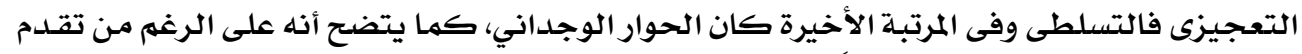

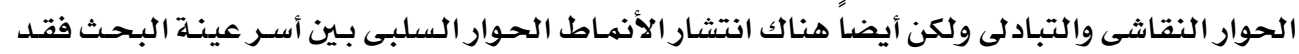

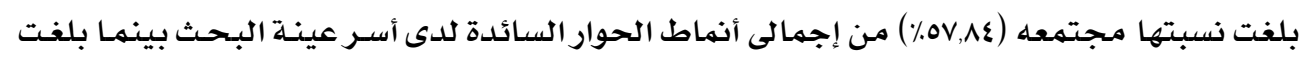

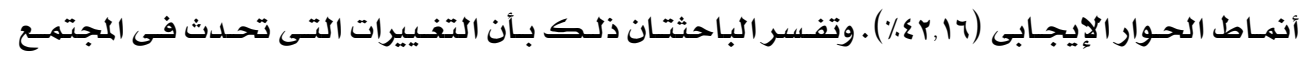

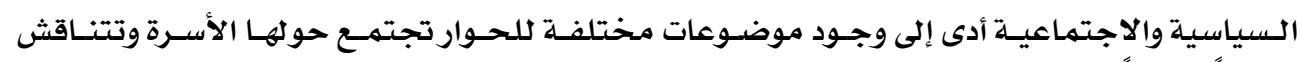

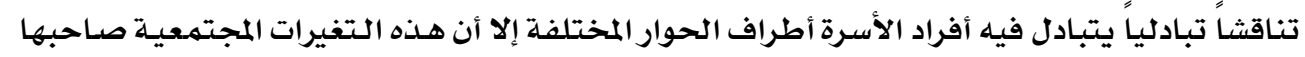

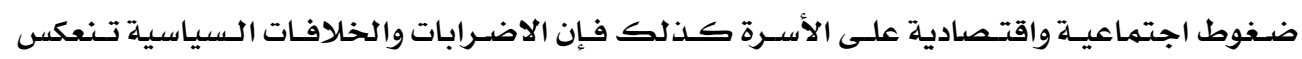

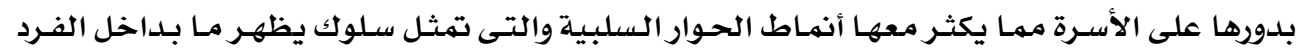
من ضغوط.

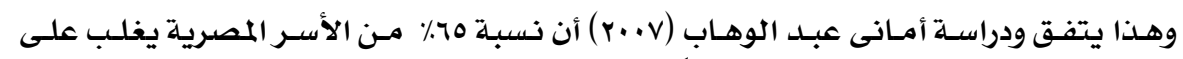

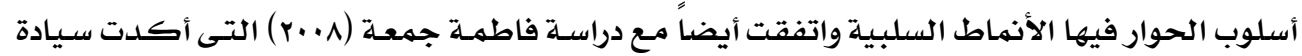

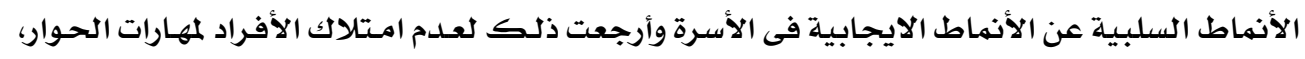

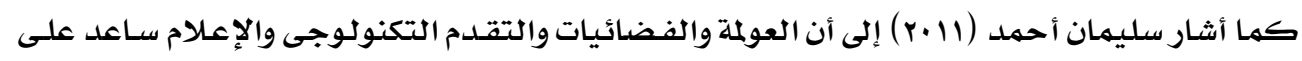

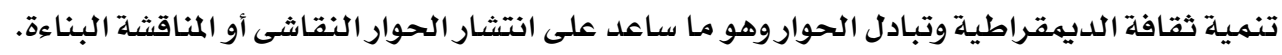

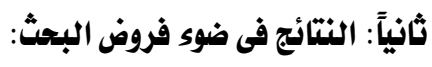

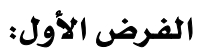

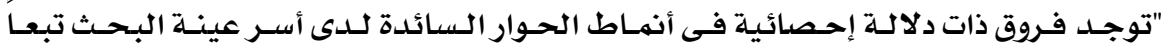

لمتغيرات المستوى الاجتهاعى والاقتصادى (تعليه الوالدين - عدد أفراد الأسرة - مستوى الدخل الدخل). وللتحقق من هذا الفرض تم إجراء: 
أ- اختبار (ت) للوقوف على دلالة الفروق بين متوسطات أنهـاط الحوار الأسـرى تبعـاً لمتغير عدد

أفراد الأسرة.

ب- تحليل التباين لايجاد قيهـة (ف) للوقوف على دلادة الفـروق فى أنهاط الحـوار الأسـرى تبعـاً

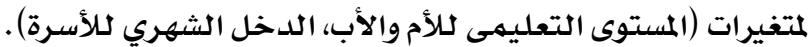

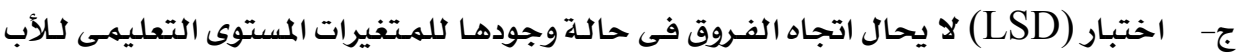

والأم، الدخل الشئرى لارل الأسرة.

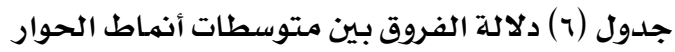

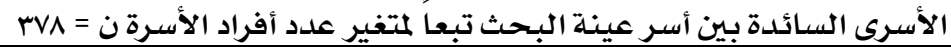

\begin{tabular}{|c|c|c|c|c|c|c|c|}
\hline مستوى الدلالة & قيمـة ت & درجات & العينـة & الانحراف & المتوسط الحسابى & علد أفراد & أنهاط الححوار \\
\hline • •. • لصسالح الأسـرة & $\varepsilon, \mu$ & rvT & ris & $\begin{array}{l}11,909 \\
17,41 .\end{array}$ & $\begin{array}{l}\vee Y, \bullet \varepsilon \cdot \\
\nearrow 0, \varepsilon \vee 0\end{array}$ & من (r : ع أفراد) (ه : ج أفراد) & الإِحوار \\
\hline ๑•. • لصالح الأسـرة & Y,Y & rvT & $\begin{array}{l}\text { ar } \\
\text { rAo }\end{array}$ & $\begin{array}{l}1 \&, 7 \mid \\
19,1\end{array}$ & $\begin{array}{l}7 \cdot, 1 Y \cdot \\
70,07 \mathrm{~V}\end{array}$ & مـن (ب : ع أفراد) & وار السلبىى \\
\hline
\end{tabular}

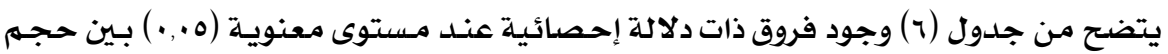

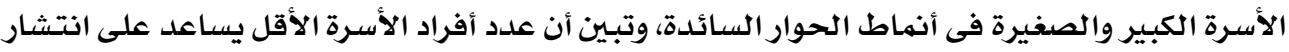

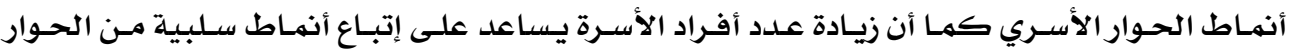

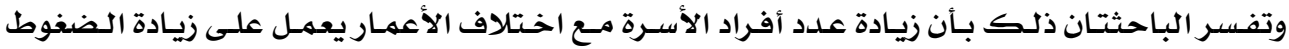

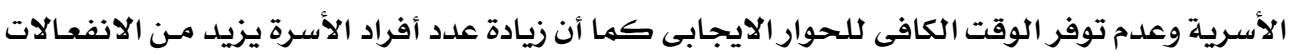

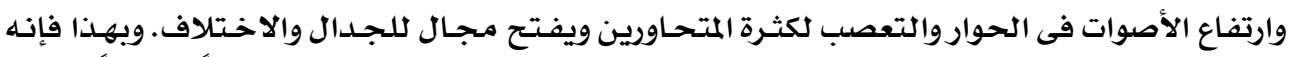

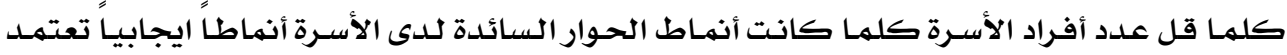

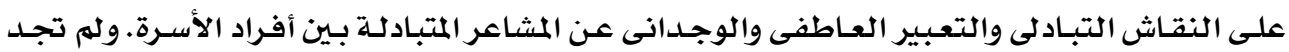
الباحثتان دراسات تناولت متغير حجم الأسرة وارتباطه بأنهاط الحير الحوار الأسرىى. 


\begin{tabular}{|c|c|c|c|c|c|c|c|}
\hline \multicolumn{8}{|c|}{ 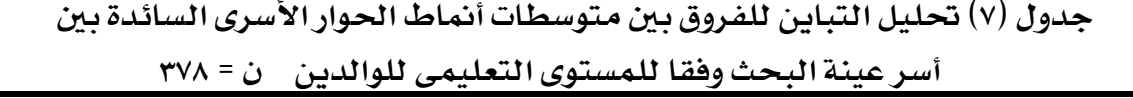 } \\
\hline 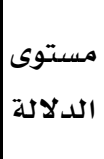 & قيمة & الحرجات & متوسط المربعات & 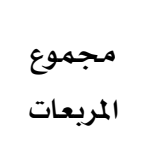 & مصدر التبـاين & المتغير & الأسماط ألمار \\
\hline$\cdot, \cdot 1$ & $\wedge r, \wedge$ & $\begin{array}{l}\text { r } \\
\text { rvo } \\
\text { rvg }\end{array}$ & $\begin{array}{l}\text { MAYr,QE } \\
\text { rro,vor }\end{array}$ & 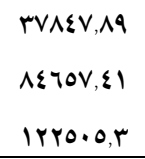 & داخل الماجسموعموعات المبـات & التعليهى للأب & 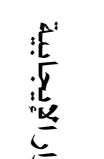 \\
\hline$\cdot, 1$ & Vo, QV & $\begin{array}{l}\text { r } \\
\text { rvo } \\
\text { rvV }\end{array}$ & $\begin{array}{l}\text { lOVY\&,Yq } \\
r \cdot V, 0 . r\end{array}$ & 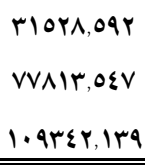 & داخل المبن المجموعات المبموعات & التعليمى لكلأم & 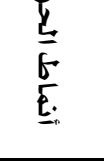 \\
\hline$\cdot, \cdot 1$ & $1 \cdot 0,1 \%$ & $\begin{array}{l}\text { r } \\
\text { rvo } \\
\text { rve } \\
\text { r } \\
\text { rvo } \\
\text { ruv }\end{array}$ & $\begin{array}{l}189 \cdot 1,70 Y \\
10 \cdot, r \wedge r \\
1 V V V 9,71 \\
179,11\end{array}$ & 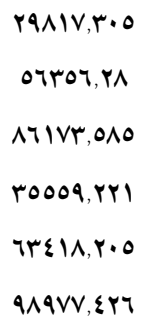 & 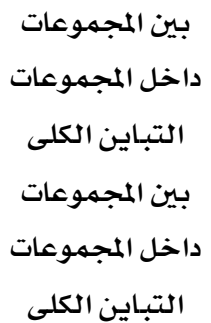 & التعليهى لكلأب التعليتوى المستوى & $\frac{E}{E}$ \\
\hline
\end{tabular}

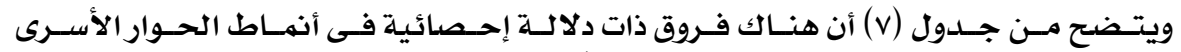

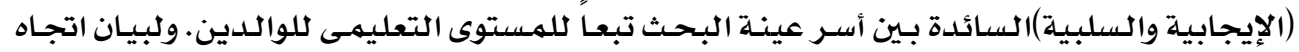

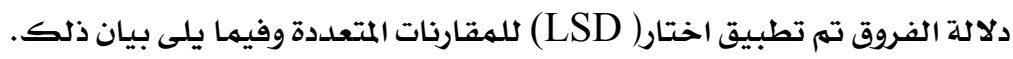


جدول (^) دلالة الفروق بين أنماط الحوار الأسرى الحي

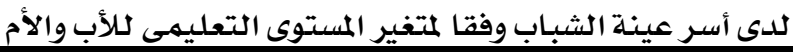

\begin{tabular}{|c|c|c|c|c|}
\hline 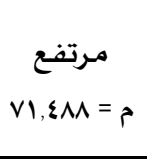 & م = •. متوسط & من منخفض & المستوى التعليهى للأب & الأنماط الحوار \\
\hline $\begin{array}{l}- \\
- \\
-\end{array}$ & $\begin{array}{c}- \\
- \\
\& \leq, \vee \wedge \wedge \\
\end{array}$ & $\begin{array}{c}- \\
\& \& \text { YI,OYA } \\
\& \& \text { YT,rIT }\end{array}$ & مترسط (ثانوى وفوق متوسط تعليم أساسى) & $\begin{array}{l}: \vec{E} \\
\cdot \sqrt{2}\end{array}$ \\
\hline 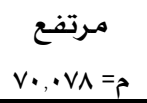 & مت = متوسط & من = منفضض & المستوى التعليهى للأم & $\underline{\underline{\xi}}$ \\
\hline- & $\begin{array}{c}- \\
* * \mid V, V V\end{array}$ & $\begin{array}{c}- \\
+1 r, \Lambda \cdot 0 \\
* * r \cdot, 0 \text {. }\end{array}$ & 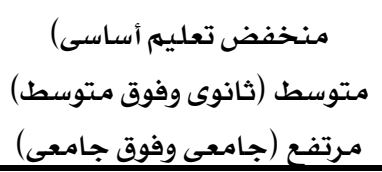 & \\
\hline $\begin{array}{c}\text { مرتفع = } \\
r V, O Y I \\
\end{array}$ & مت = متوسط & من = . منخفض,r. & المستوى التعليمى للأب & \\
\hline $\begin{array}{l}- \\
- \\
-\end{array}$ & $\begin{array}{c}- \\
- \\
\& \& Y \backslash, \wedge q \vee\end{array}$ & $\begin{array}{c}- \\
\& 1 \varepsilon, 9 \cdot r \\
\& \& 44, V 99\end{array}$ & مترسط (ثانوى وفوق متفوسط أساسى) & $F$ \\
\hline مر مرتفع & 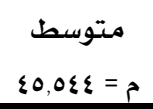 & من م = r. r & المستوى التعليهى للأم & $\bar{\xi}$ \\
\hline- & $\begin{array}{c}- \\
\& \text { \&, \&rv }\end{array}$ & $\begin{array}{c}- \\
\& \& \text { YY,VOT } \\
* \& \text { rY,I9Y }\end{array}$ & مترسط (ثانوى وفوق متوسطى منسيم) & $\underline{E}$ \\
\hline
\end{tabular}

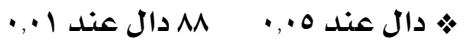

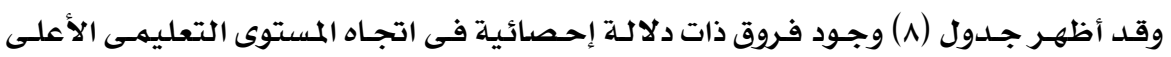

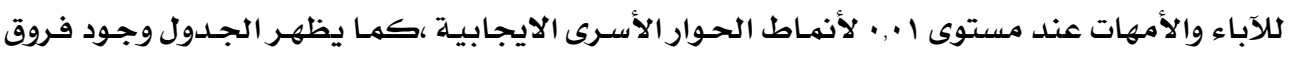

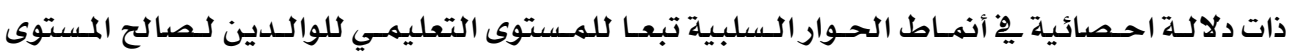

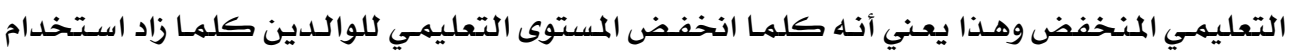

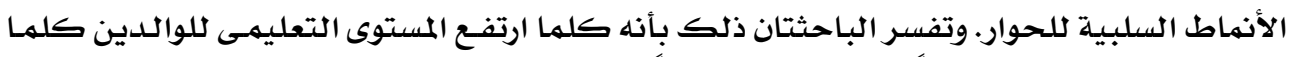

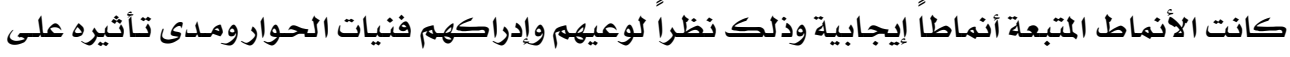

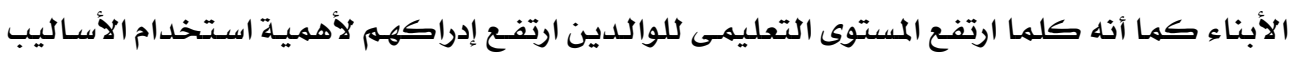




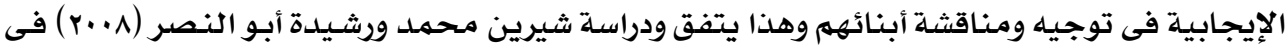

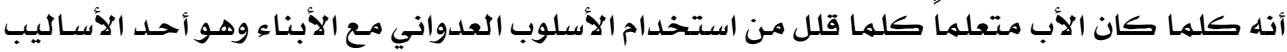
والأنهاط السلبيـة.

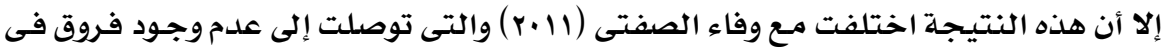

النهط الديهقراطى والنمط الدكتاتورى المتبع فى الأسرة وفقا للهستوى التعليهى للوالدالدين.

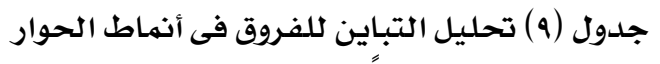

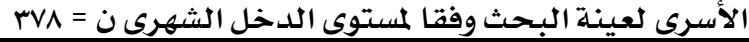

\begin{tabular}{|c|c|c|c|c|c|c|}
\hline مستوى الدلانة & قيمة & الحرية & متوسط & مجموع المربعات & مستوى الدخل & الأنهاط الحوار \\
\hline \multirow{2}{*}{ غير دال } & \multirow[t]{2}{*}{$0 . \cdot 19$} & $\begin{array}{c}\text { r } \\
\text { rvo }\end{array}$ & $\begin{array}{l}\mid 0 V, \wedge \leqslant 0 \\
\mu_{1, \varepsilon \leqslant \wedge}\end{array}$ & $\begin{array}{l}\text { r10,7q } \\
\text { IIVar,r. }\end{array}$ & داخل المجنموالمجموعات & \multirow{2}{*}{ 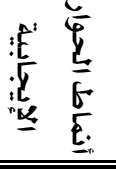 } \\
\hline & & rvv & & $|Y| \cdot \Lambda, 19$ & التبـاين الكلى & \\
\hline \multirow[t]{2}{*}{ غير دال } & \multirow[t]{2}{*}{$0,7{ }^{\prime}$} & $\begin{array}{c}\text { r } \\
\text { rvo }\end{array}$ & $\begin{array}{l}r \cdot r, 700 \\
r .111\end{array}$ & $\begin{array}{l}\varepsilon \cdot V, r \| \mid \\
\mid r o s \varepsilon, r q\end{array}$ & داخل المجمـوعات المجموعات & \multirow{2}{*}{ 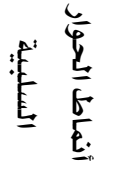 } \\
\hline & & & & $1 \mathrm{ra} 901,0 \mathrm{VI}$ & التباين الكلي & \\
\hline
\end{tabular}

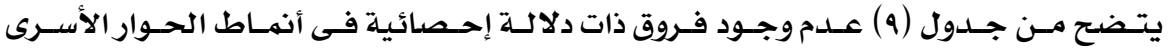

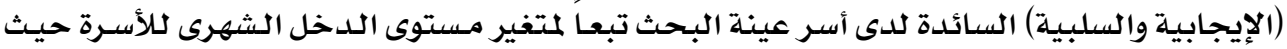

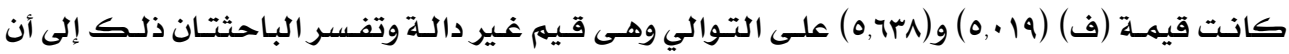

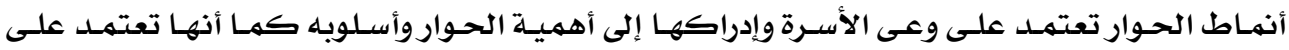

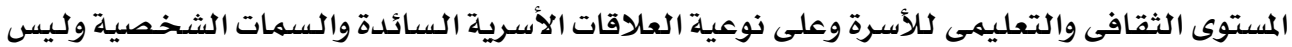

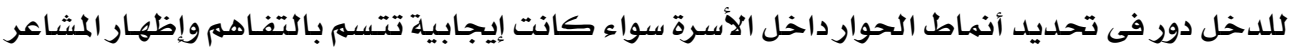

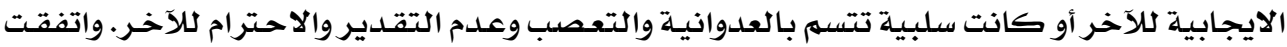

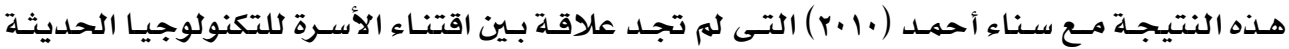

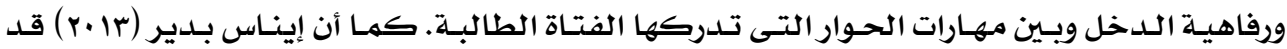

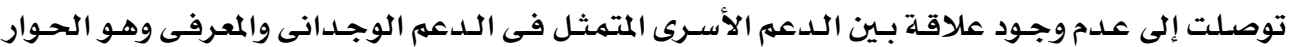

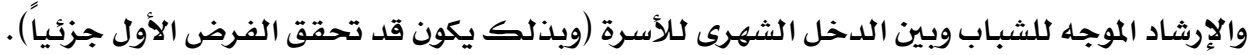
الفرض الثانى:

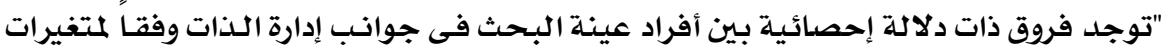

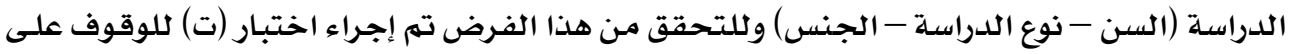




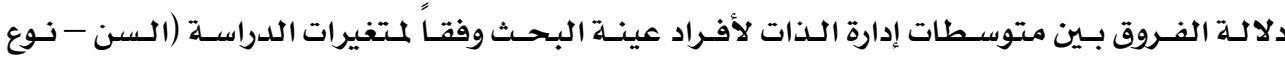

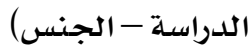

جدول ( • ا ) دلالة الفروق فى إدارة الذات

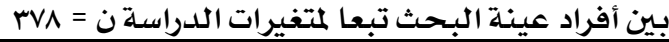

\begin{tabular}{|c|c|c|c|c|}
\hline مستوى الدلالة & 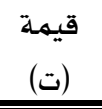 & الانحراف & المتوسط الحسابى & 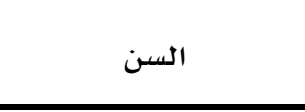 \\
\hline 1 إل دالة لصالح المرحلة & $\mid \varepsilon,\{9 \mid$ & $\begin{array}{l}11, r . \\
\Lambda, 0 \mathrm{~V}\end{array}$ & $\begin{array}{l}\text { ov,lor } \\
\text { Er,TrY }\end{array}$ & من 19 ما إلى أقل من 19 إقل من إم عام عام 19 عن \\
\hline مستوى الدلادلة & $\begin{array}{l}\text { قيمـة } \\
\end{array}$ & الانحراف & المتوسط الحسابى & الجنس \\
\hline غير دالة & •, IVq & $\begin{array}{l}|\Lambda, T| \\
\text { YI,YrYT }\end{array}$ & $\begin{array}{l}\text { Tr,or1 } \\
\text { T0,NI. }\end{array}$ & بنين \\
\hline مستوى الدلادة & قيمة & الانحراف & المتوسط الحسابى & نوع الدراسة \\
\hline ال•,• دالة لصـالح & MA,Vr. & $\begin{array}{l}7, \cdot r \\
9,1 \wedge \varepsilon\end{array}$ & $\begin{array}{l}\{1,0 V \\
7 r, 0 r\end{array}$ & نظرية \\
\hline
\end{tabular}

يتضح من جدول ( م ) وجود فروق ذات دلالة إحصائية بين أفراد عينـة البحث في إدارة الدات

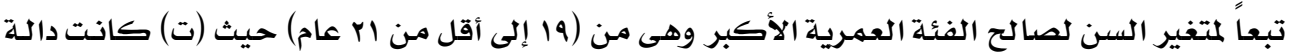

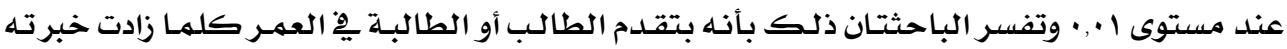

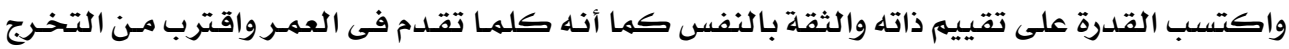

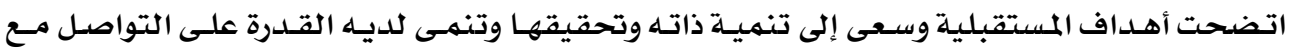
الآخرين وهذه هي جوانب إدارة الذات.

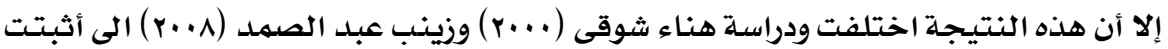

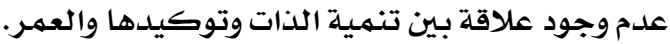

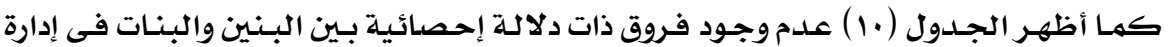

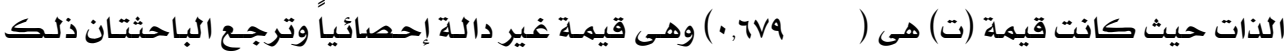

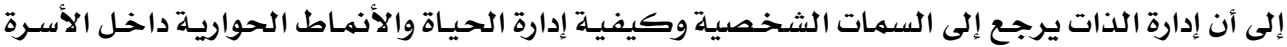

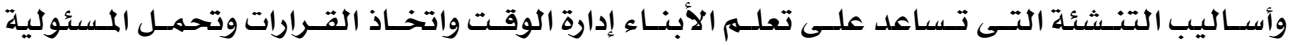

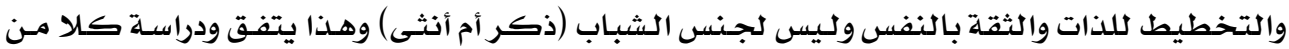

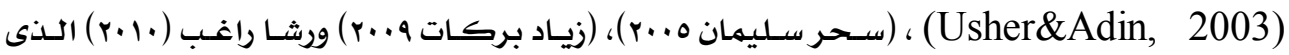

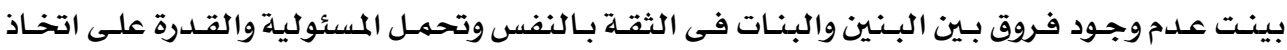




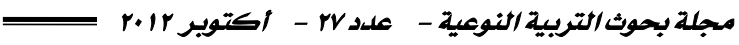

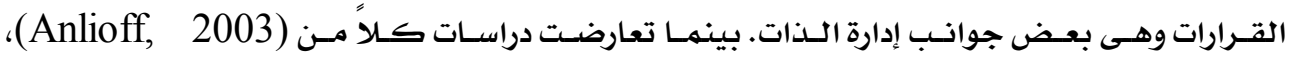
التى أشارت إلى وجود فروق فـى تقـدير الدات ومستوى الطهـوح يرجـع إلى (Margoribank, 2004) الجنس لصالح الذكور.

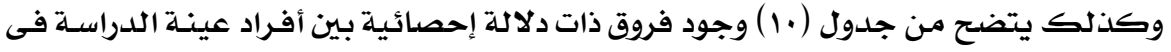

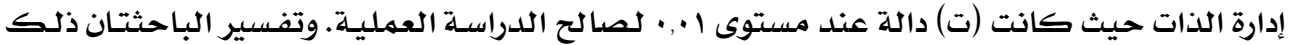

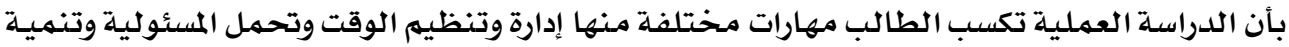

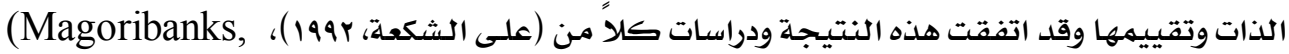
(Black burn, 2002), (Bandey, 2002) درجات تقدير الذات والطموح وتنمية الذات تبعاً لمتغير التخصص وذلك لصالح التخصصات العملية.

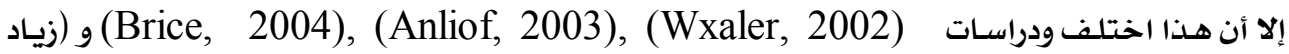

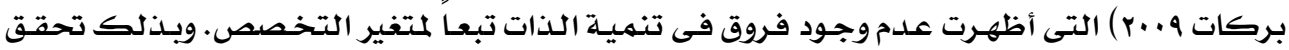
الفرض الثانى جزئيا. الفرض الثالث:

"توجــ علاقـة ارتباطيـة بـين أنهـاط الحـوار الأسـرى السـائدة فـى أسـر عينـة البحـث وبـين إدارة

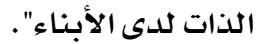

وللتحقـق مـن هـذا الفـرض تم حسـاب معامـل ارتبـاط بيرسـون لايجـاد العلاقــة بـين مقيـاس

أنهاط الحوار الأسرى ومقياس إدارة الذات للأبناء. جدول (11) مصفوفة معاملات الارتباط بين أنماط الحوار الذات لأناء

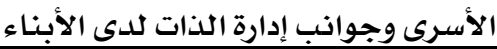

\begin{tabular}{|c|c|c|c|c|c|c|c|}
\hline \multirow[b]{2}{*}{ السلبي ككل } & \multicolumn{3}{|c|}{ أنفاط العوار السلبي } & \multirow[b]{2}{*}{ ككل الإيجابي } & \multicolumn{2}{|c|}{ أنفاط الحوار الإيجابي } & \multirow{2}{*}{ محاور إدارة الذات محاور أنهاط الحوار الأسرى } \\
\hline & العدواني & التسلطي & التعجيزى الحوار & & الوجداني & التقاشى التبادلي & \\
\hline$\pm \pm \times, v \leqslant 0$ & $\mathbb{X}^{*} \cdot, \mathrm{VYT}$ & $\mathcal{*}^{*} \cdot, \mathrm{rrv}-$ & *., TाL & $\pm * 0,107$ & $\pm \dot{x} \cdot, 7 \cdot r$ & $\dot{*} \dot{x} \cdot, r \vee y$ & | وضع الأهداف والتخطيط للذات | \\
\hline $\pm * *, 797$ & $\pm * *$, v7o & $* \cdot, T r \varepsilon$ & $\mathbb{X}^{*} \cdot \operatorname{VAr}-$ & $\dot{*} * \cdot \wedge \leqslant v$ & 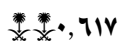 & $\dot{x} \cdot, n \xi$ & تقويم ورقابة الذات \\
\hline $\mathbb{X}^{*} \cdot$ : Arq & $* \cdot$, yor_ & $\mathbb{X} \times \cdot, \wedge \wedge 7$ & $\dot{x} \cdot 9 \cdot \varphi$ & $\dot{x} \pm \cdot, \wedge r q$ & $\dot{*} \dot{*} \cdot \mathrm{rrT}$ & $\pm \cdot, 997$ & الاتصال الفعال \\
\hline$\dot{*} * \cdot A \mathrm{AKL}$ & $\pm * * 9 \cdot 9$ & $x+2 \cdot 9 \cdot \varepsilon$ & •,ATE & $\dot{*} * \cdot \wedge \mathrm{*}$ & $\dot{*} * \cdot 9 r$ & $\frac{*}{x} \cdot, \wedge 1 r$ & القدرة على تنظيه الوقت \\
\hline$\dot{x} \cdot$, VIr- & 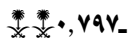 & $\mathbb{X}^{*} \cdot, \mathrm{VAr}-$ & $x^{*} \times \cdot$, ท91 & $\mathbb{X}^{*} \cdot, \wedge \wedge \mathrm{r}$ & $+* *$, Aro & $x^{*} \times \cdot, \wedge 91$ & | اتخاذ القرارات وتحمل المسئوليات | \\
\hline $\pm * *$ : Aro_ & $\dot{*} *$ VYr. & * $\times 14 \varepsilon$ & $x^{*} \cdot$, arr- & $\pm * *, 110$ & 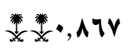 & $x+* \cdot 9 r v$ & | الثقة بالنفس \\
\hline$\frac{*}{x} \cdot v \cdot 1$ & $x^{*} \times, 797$ & $x^{*} \cdot v \cdot r$ & $\dot{*} \cdot$, VIr & $\pm * * \cdot 1 \cdot 0$ & $* *, 7 \leqslant r$ & $\dot{x} \times \cdot, \lambda \cdot \cdots$ & تطوير وتنمية الذات \\
\hline$\pm \pm \cdot$, ATO_ & $x_{X}^{*} \cdot, A r V_{-}$ & $x^{*} \cdot r \leqslant 7$ & $x * x \cdot \wedge 7 V_{-}$ & $\dot{x} \times \cdot, \wedge 7 \varepsilon$ & $\mathbb{X}^{*} \times \cdot, \operatorname{AAr}$ & $\mathbb{X}^{*} \times \cdot, \mathrm{Arr}$ & المقياس ككل \\
\hline
\end{tabular}

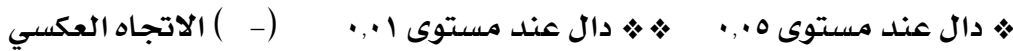




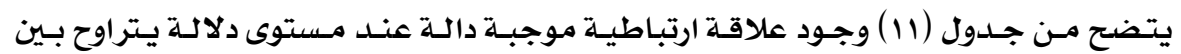

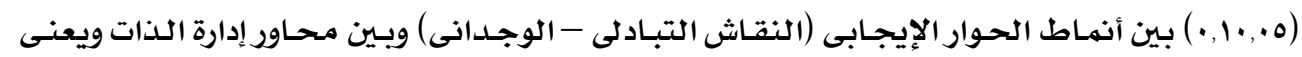

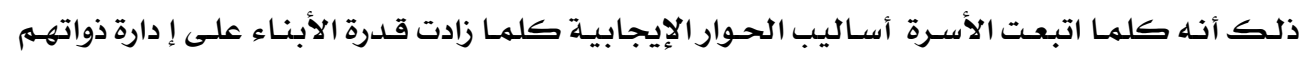

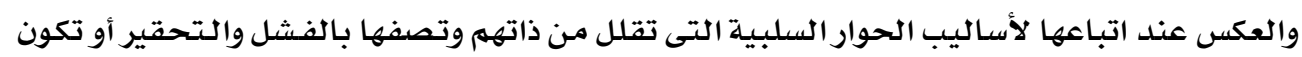

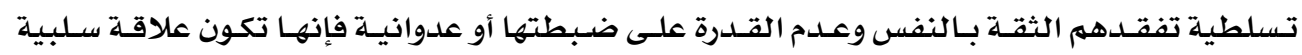

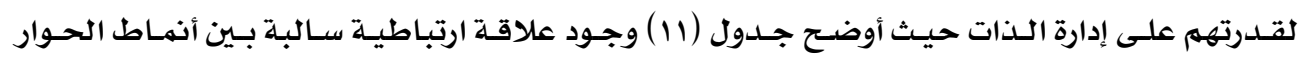

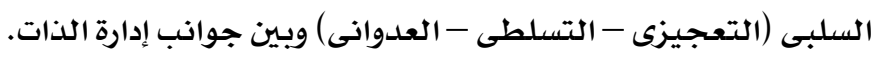

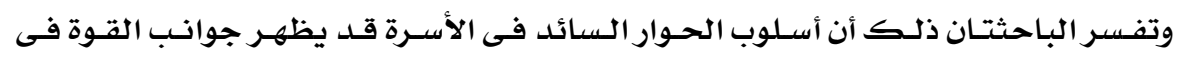

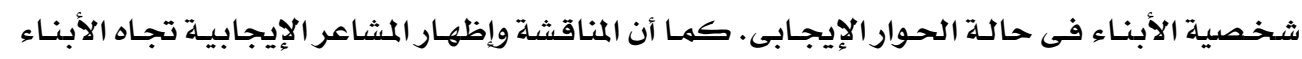

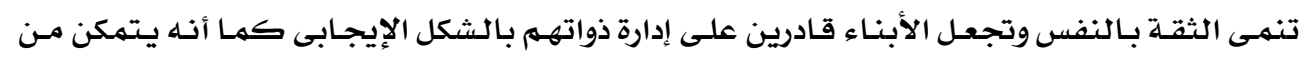

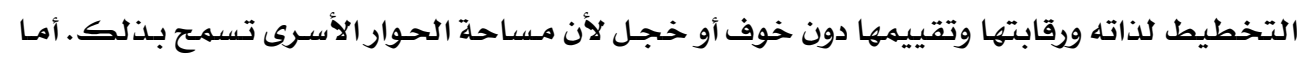

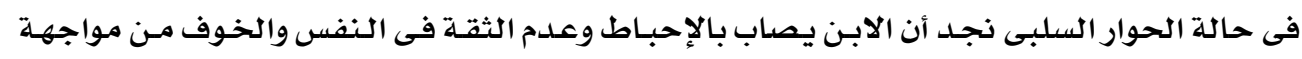

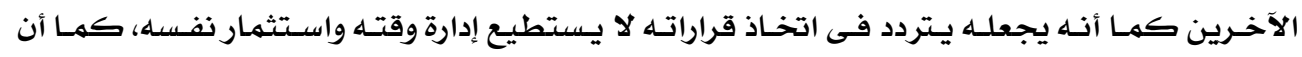

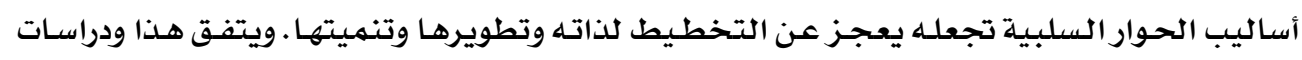

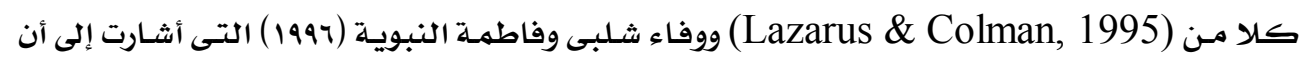

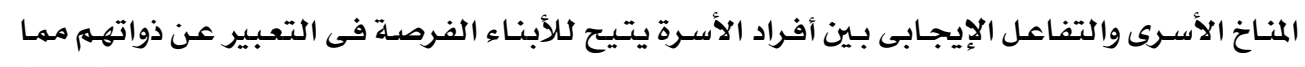

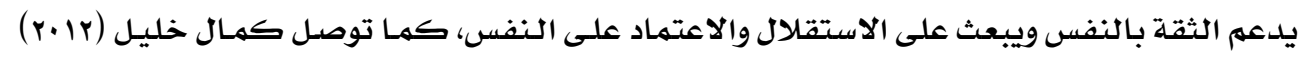

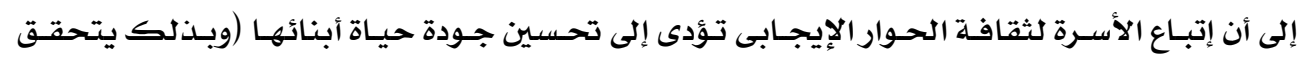
الفرض الثالث). الفرض الرابع:

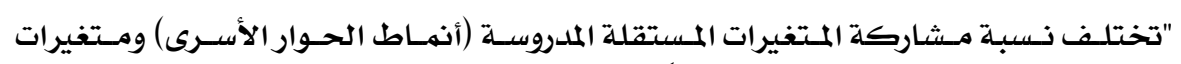

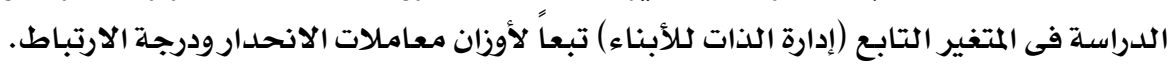

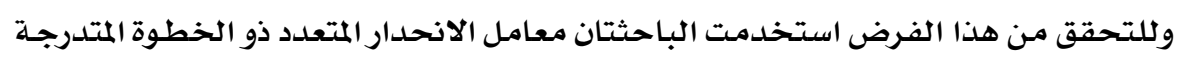

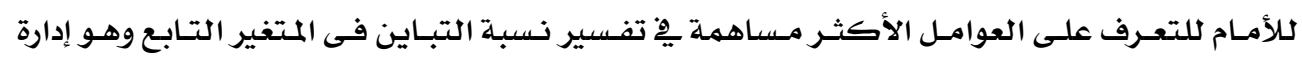
الذات للأبناء. 
جدول (r ) معامـلات الانحدار باستخدام الخطوة المتدرجـة للأمام

\begin{tabular}{|c|c|c|c|c|c|c|c|c|}
\hline مستوى & قيمة (ت) & 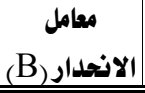 & مستوى & 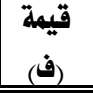 & المشاركة المبة & $\begin{array}{c}\text { معامل } \\
\text { R الارتباط }\end{array}$ & المتفيرات المستقالة & المتفير التابع \\
\hline$\cdot, 1$ & ro, 70 & •, qrr & $\cdot, 1$ & $\Lambda 0, r \wedge r$ & $\bullet, \Lambda V$. & •, arr & الحوار التبادلي (النقاشى) & \multirow{6}{*}{ إدارة الذات } \\
\hline$\bullet, 1$ & $r \wedge, 199$ & $\cdot, r \cdot v$ & $\cdot, 1$ & $V \varepsilon, 1 Y \varepsilon$ & $\cdot, 9+7$ & $\cdot, 90 \mathrm{r}$ & المستوى التعليمى للوالدين & \\
\hline$\cdot, 1$ & $\mathrm{Mq}, \wedge \wedge 9$ & $\bullet,|T|$ & $\cdot, 1$ & $01,0.1$ & $\cdot, \mathrm{V} \leq \varepsilon$ & •,Аฯr. & الحوار التمجيزى & \\
\hline$\cdot, 1$ & $17, \wedge 9 \mathrm{~V}$ & $\cdot, \wedge 7 r$ & $\cdot, 1$ & $\sum r, \Lambda \cdot 1$ & $\cdot, 919$ & $\cdot, 909$ & الحوار الوجدانى & \\
\hline$\cdot, 1$ & ร, $7 Y$. & $\cdot, 1 \wedge \varepsilon$ & $\cdot, 1$ & rA, l. & •, マ৭. & $\cdot, \wedge \wedge 9$ & نوع الدراسة & \\
\hline$\cdot, 1$ & $r, \$ 19$ & •, r & $\cdot, 1$ & $r r, \cdot \cdot$ & $\cdot, 707$ & •,Al•- & الحوار العدواني & \\
\hline
\end{tabular}

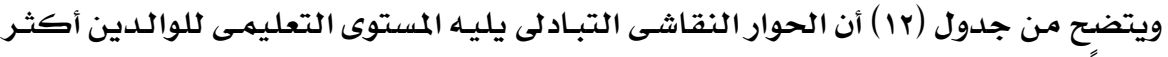

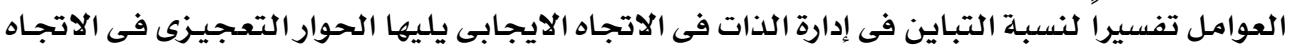

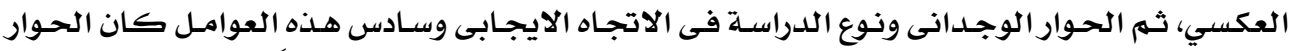

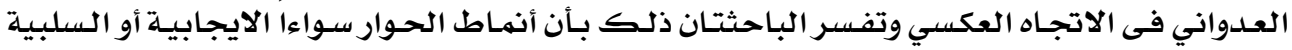

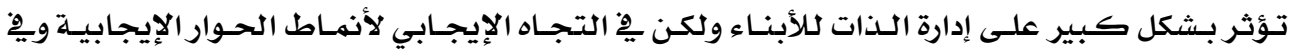

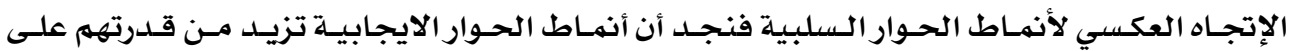

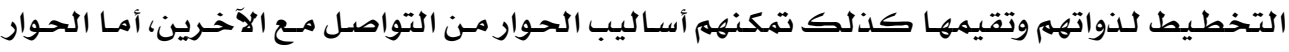

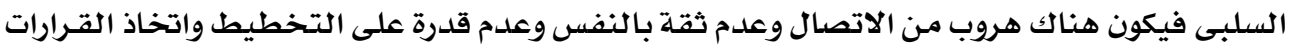

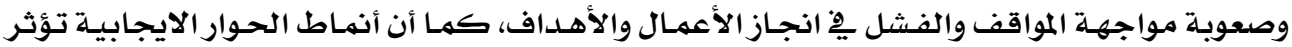

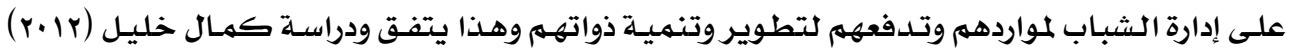

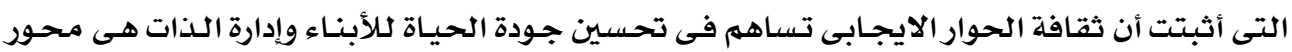

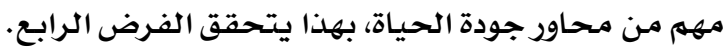

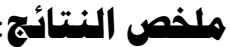

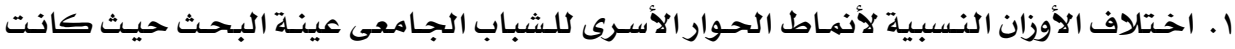

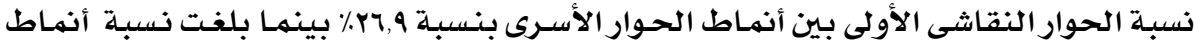

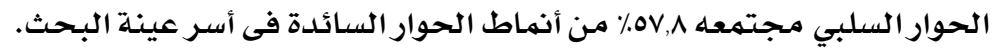

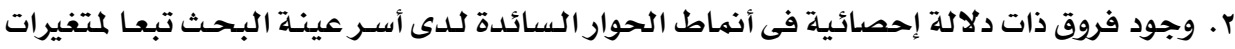

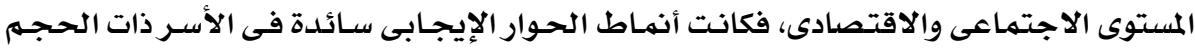

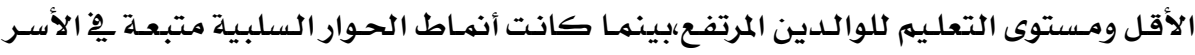

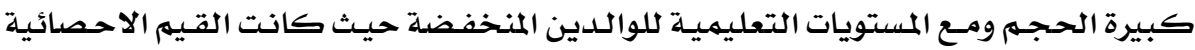

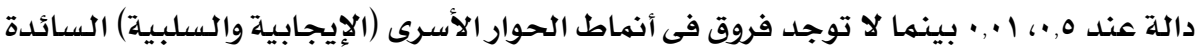

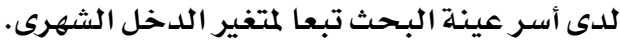


r. وجـود فروق ذات دلالـة إحصائية بـين أفراد عينـة البحث فى جوانب إدارة الـذات فكانت لصـالح

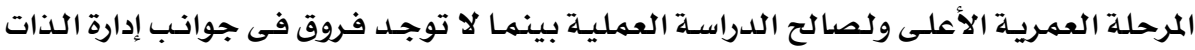
بين البنين والبنات في عينة البحث.

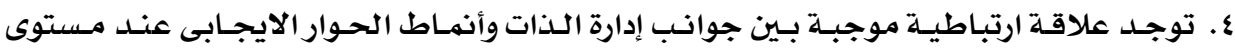

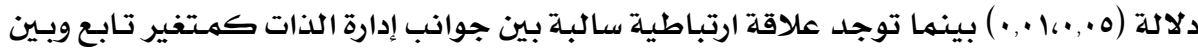

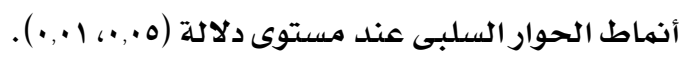

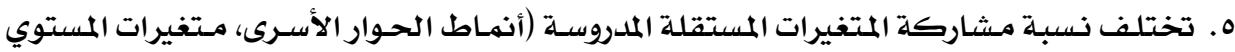

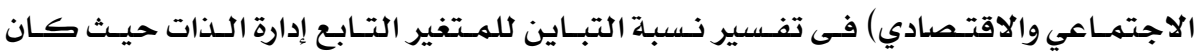

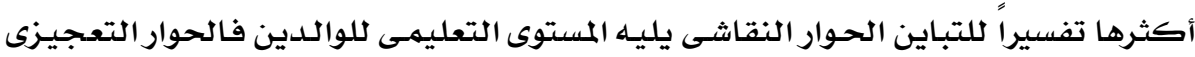

$$
\text { وكان أقلها الحوار العدواني. تفيرانين. }
$$

\section{برناهج إرشادي هقترح لتنهية فنيات الحوار الحواني.}

خطوات إعداد البرنامج:

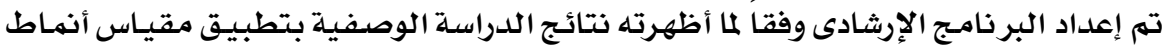

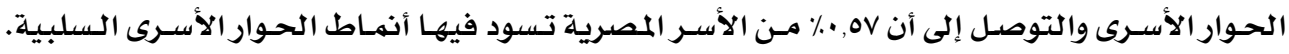

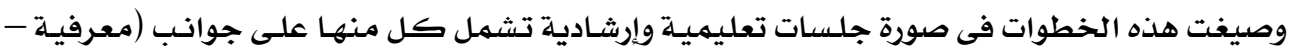

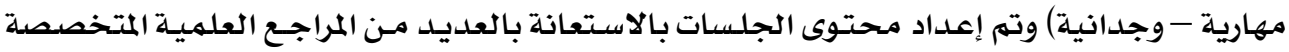

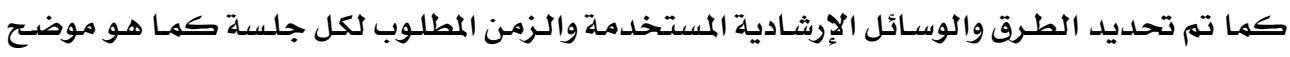

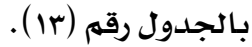

\section{الفئة المستهلفة:}

$$
\text { الشباب لتوعيتهم بأنماط الحوار الأسرى وفنيات الحوار الإيجابى. }
$$

محتوى البرنامج:

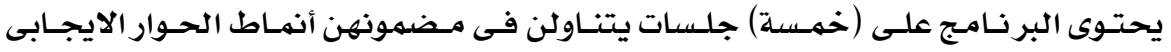

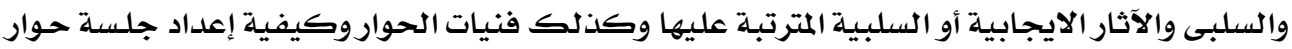
بناءة وإدارة الحوار بشكل جيدالد. تقتيييم البرنامج: يتهم تقييم البرنامـج من خلال: التقيييم المبلدئى من خلال طرح عدة أسئلة عن محتوى الجلسة وربطها بالبرنامج. التقييه النهائى لكل جلسة: من خلال طرح عدة أسئلة فى نهاية الجلسة للتأكد من مدى الاستيعاب لمحتوى الجلسـة. 


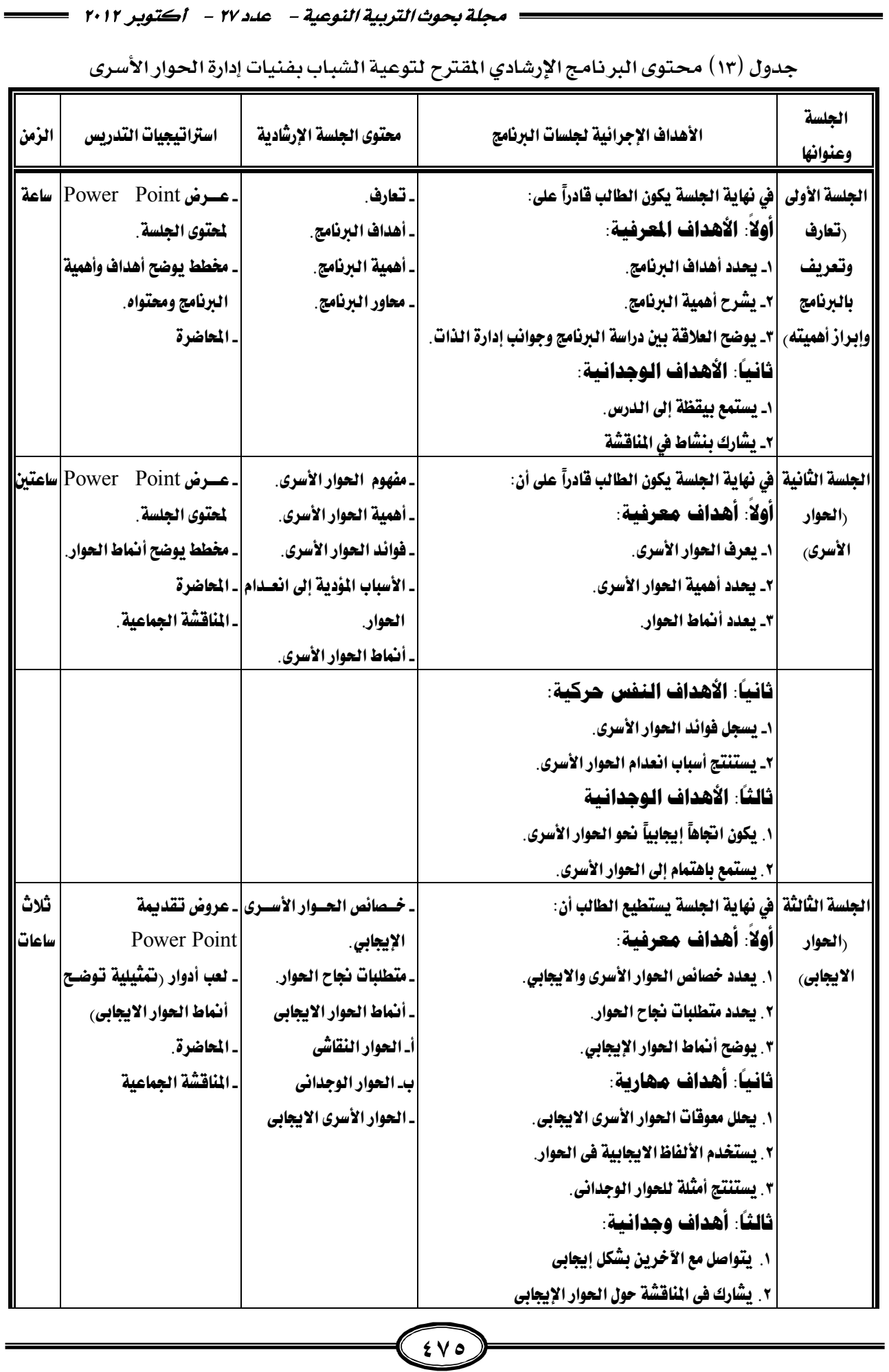


إ_انماط الحوار الأسرى ووعلاقتها بإدارة الذات للى الأبناء

\begin{tabular}{|c|c|c|c|c|}
\hline | - الزمن & استراتيجيات التدريس & محتوى الجلسة الإرشادية & الأهداف الإجرائية لجلسات البرنامج & وعنوانها \\
\hline شاعات & 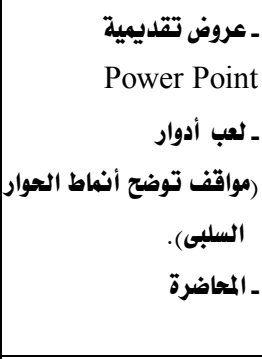 & 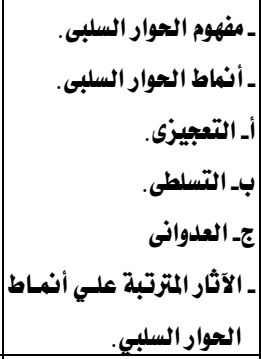 & | فأولاً: أهداية الجلسة يستطيع الطالب أن: & |الجلسة الرابعة \\
\hline & & & 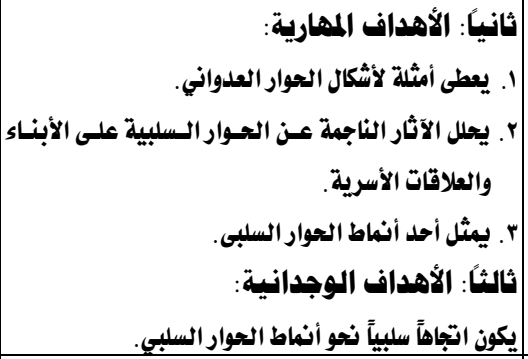 & \\
\hline |أربع & 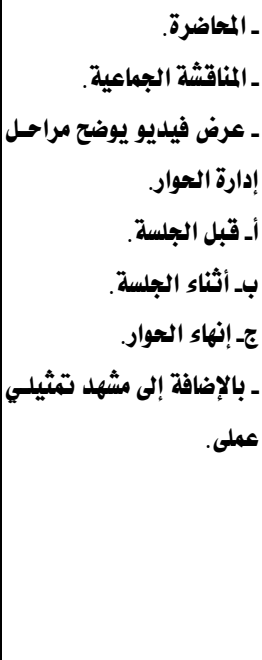 & 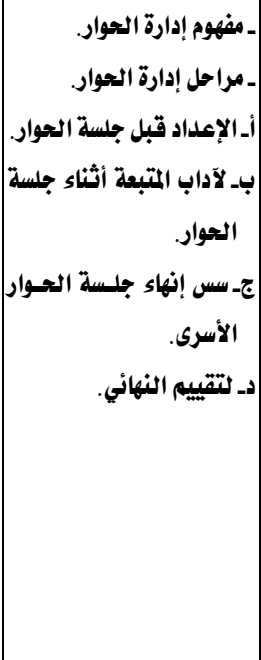 & 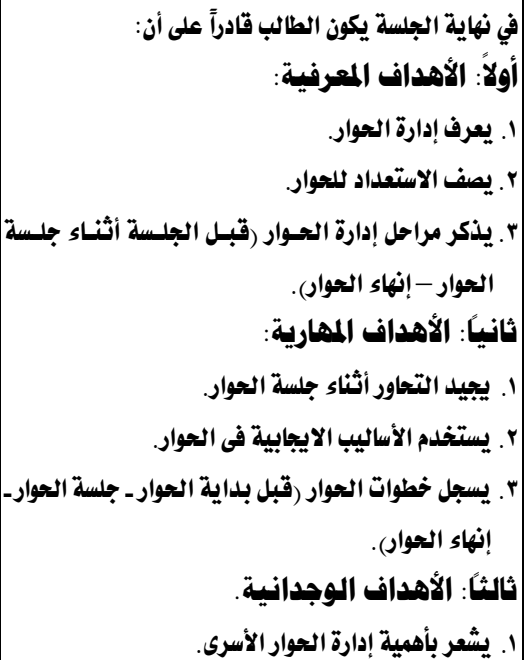 & 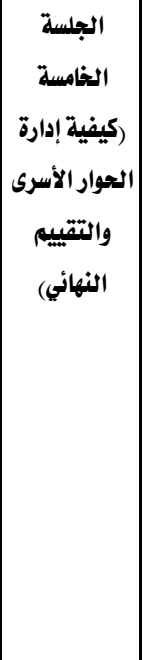 \\
\hline
\end{tabular}




\section{توصيات البحث:}

ا ـ تطبيق الباحثين والدارسـين المتخصصين يفّادارة مؤسسـات الأسـرة والطفولـة للبر نـامج المقترح

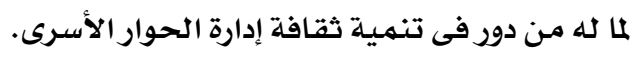

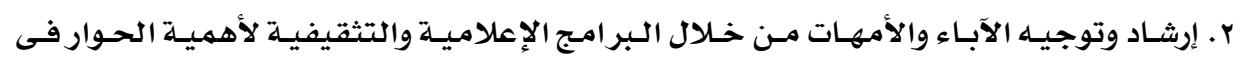
ترسيخ جوانب إدارة الذات لدى الأبناء.

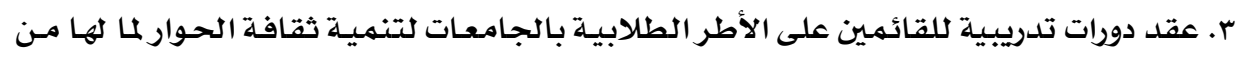
دور فى تشكيل الذات وتنميتها.

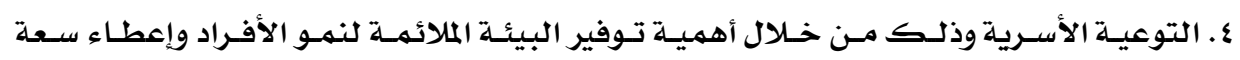

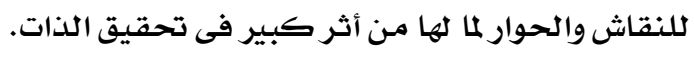

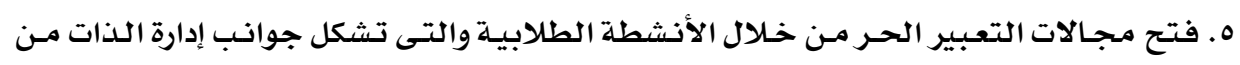

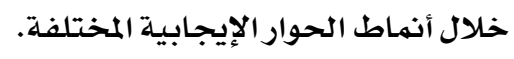




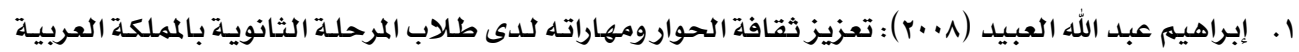

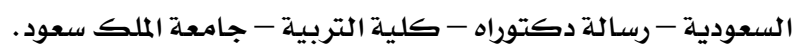

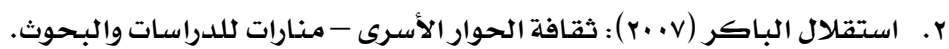

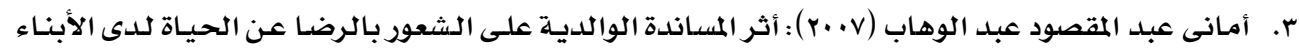

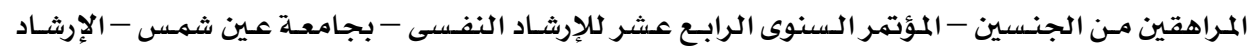

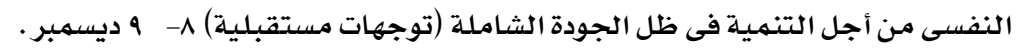

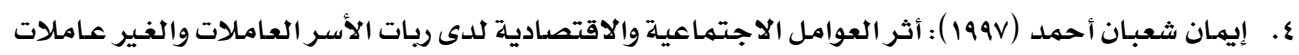

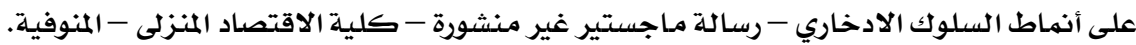

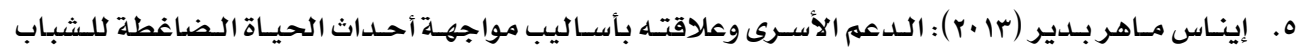

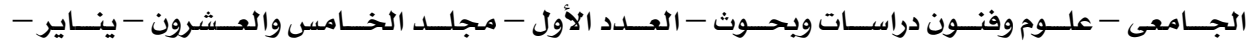
جامعة حلوان. ז. جابر عبد الحميد وعلاء الدين كفافى (1990) : معجم علم النفس والطب النفسى - الجزءء السـابع - دار النهضة العربية - القاهرة.

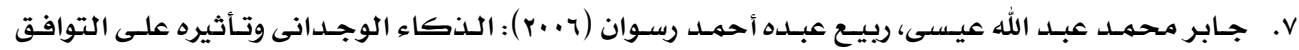

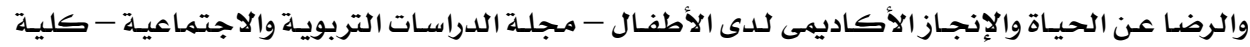
التربية - جامعة حلوان.

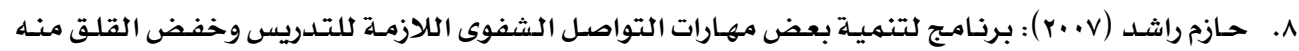

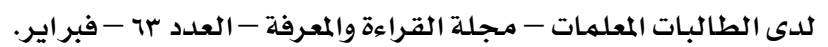

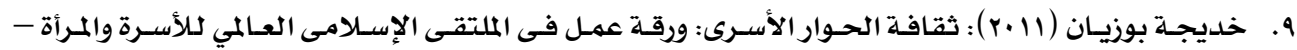

$$
\text { الخرطوم - السودان. }
$$

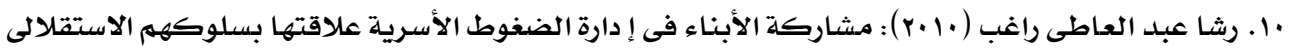

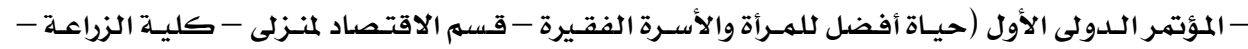

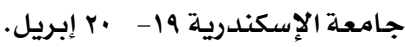

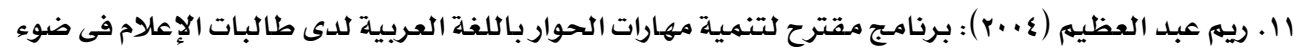

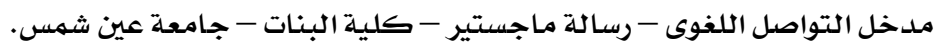

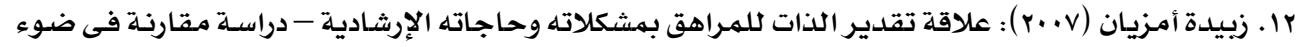

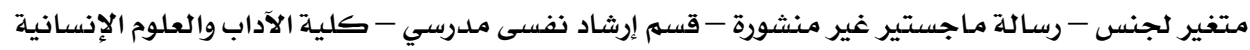
- جامعة الحاج لخضر - باتنة - الجزائر.

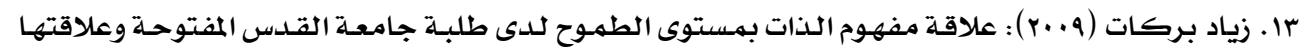

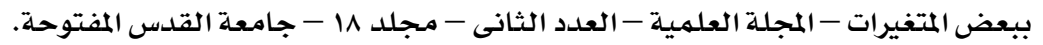




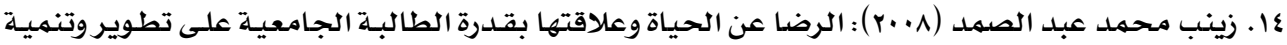
الذات - مجلة بحوث الاقتصاد المنزلى - مجلد (N|) - العدد (r) - جامعة المنوفية.

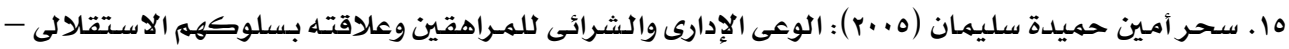
رسانة ماجستير غير منشورة- كلية الاقتصداد المنزلى - جامعة المنوفية.

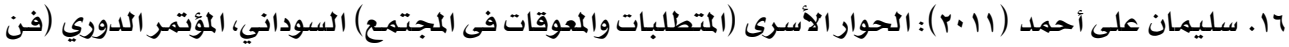
الحـوار الأسـرى) - الطريـق إلى الـسعـادة - مـركـز ثقافـة التتميـة الاجتهـاعيـة - وزارة الرعايـة والـضمـان

$$
\text { الاجتهماعى - الخرطوم - السودان. }
$$

IV . سناء الخولى (r/911) : الزواج والعلاقات الأسرية - دار المعـارف الجامعية - الإسكندرية.

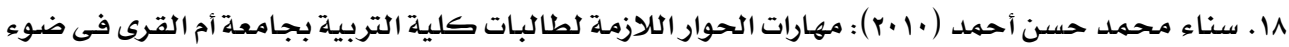
متغيرات العصر ومستجداته وقياس مدى تمكهن مـن تلـك المهارات - مجلـة القـراءة والمعرفة - العـدد هوه -

$$
\text { يناير - معهد البحوث التربوية - جامعة القاهرة. }
$$

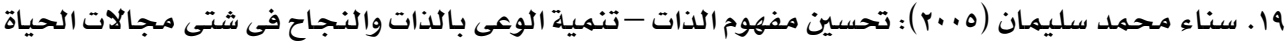

$$
\text { - عاله الكتب - القاهرة. }
$$

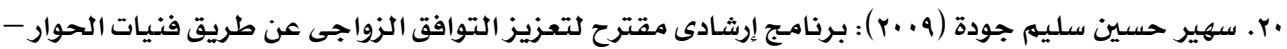

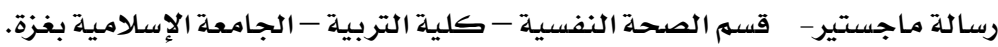
ا ا. . سيد الهواري ( (1999) ): مـلامح مدير المستقبـل - مكتبـة عين شمس - القاهرة.

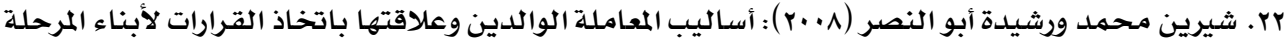

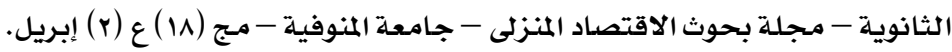
rr. صموئيل حبيب (1991) : فن الحوار - الطبعة الثالثة - دار الثقافة - القاهرةز عץ. عبد الفتاح محمد دويدار (1999) : سيكولوجية العلاقة بين مفهوم الذات والاتجـاهات - دار المعرفة الجامعيلة - الإسكندريـة. هr. عبد القادر الشيخلى (س991 ) : أخلاقيات الحوار - دار الشروق للنشر والتوزيع - عمـان.

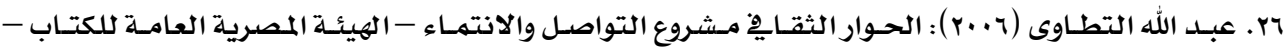
القاهرة.

مV

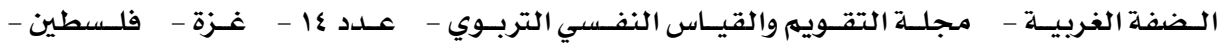
جامعة الأزهر.

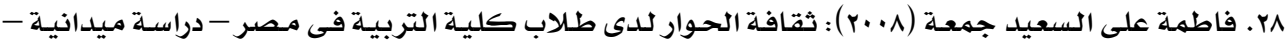
مجلة دراسات فى التعليم الجامعى - العدد الثامن عشر - أغسطس.

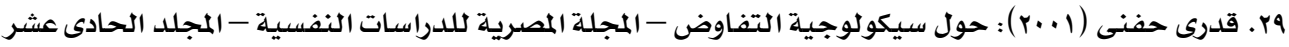
- العدد بr بوليو. 
•r. كمال كامل خليل (r (r) ): فاعلية برنامـج إرشادى لتنميـة ثقافة الحوار وعلاقتها بتحسين جودة الحياة

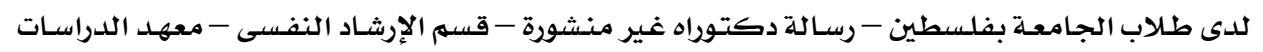
التربوية - جامعة القاهرة.

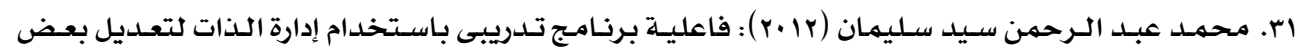

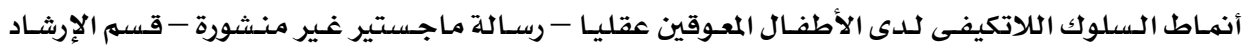
النفسى - معهد الدراسات التربوية - جامعة القاهرة.

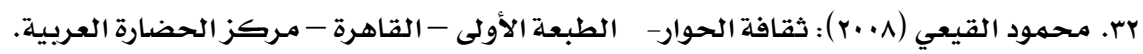

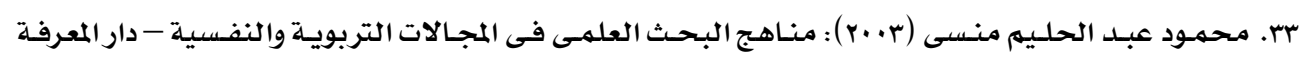
الجامعية - الإسكندرية.

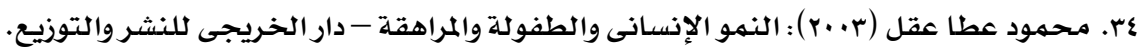

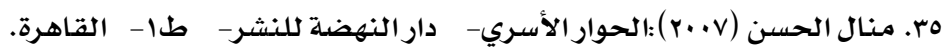

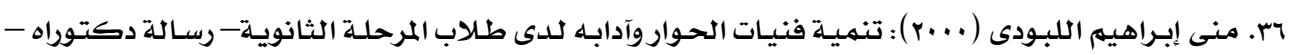

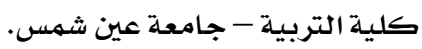

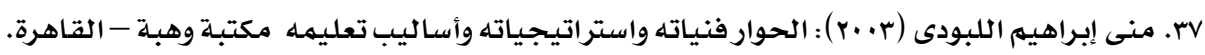

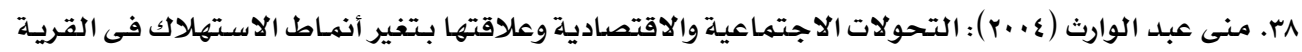

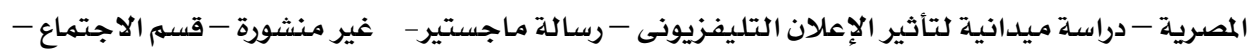

$$
\text { كلية الآداب - جامعة المنوفية. }
$$

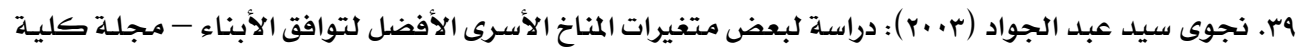

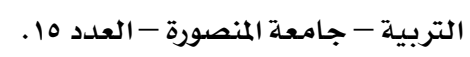

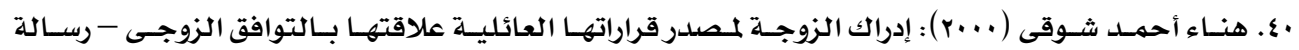

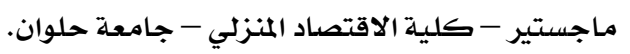

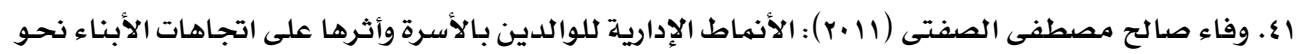

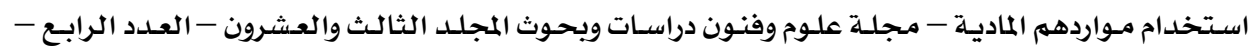
أكتوبر - جامعة حلوان.

بع. وفاء فؤاد شلبي، فاطمة النبوية إبراهيم (1991) : المناخ الأسرى وعلاقته باتخاذ الأبناء المراهقين للقرارات -

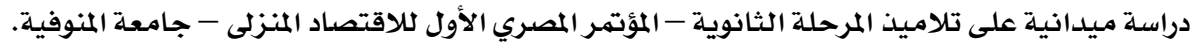

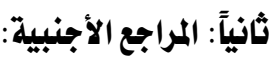

43.Aniloff, L. (2003): The relationship between high school programme and self consept. Occupational aspiration Diss. Abst. Int. V. 40(A)N 124564.

44.Bandey, B. (2002): Level of aspiration of science and arts college students in relation to neuroticism and etraversion" Indian Psychological Review. V. 32 N. 7. 


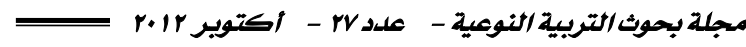

45.Bela H. Banth Patrick M. Jenlink (2005): Dialogue as a means of collective communication. New York. Kalwer Academic.

46.Blackburn S. (2002): Relationship of selected variables to occupational and educational aspiraton. Diss. Int. V 35, (A) N 71975.

47.Brice P. (2004): Locus of control self consept and level aspiraton. Journal of Oersonality Assessment. V. 69, N. 6.

48.Buckman, Steve (2000): Don't forget about self management Bloomington. In: Indiana Resources Center for Autism.

49.Eliot, F.I. (1993): Ego development Family Environment and empathy as predicator variables of moral development among male juvenile delinguents, dissertation agstmacts international.

50.Margoribanks K. (2004): Ability and personality correlates of young adults attitudes and aspirations, Psychology abstracts, V. 74 N3.

51.Patterson James I. (2002): Personality Style Consideration In Effective Dialogue. Journal \& Aggression. Vol 4. No. 1.

52.Roegel, RL. \& Park DR (1995): Teach the individual model of generalization. Autonomy through. Self-management. Blatimore: MD. Paul H. Brooks Publishing.

53. Stephen M. Edelson (2008): Self management.

(http://www.autism.org/selfmanage.html)

54.Usher. T \& Adin R (2003): self Consept of Students with orthopedic disabilities. Diss. Abs. Int. Vol 44 AN. 233.

55.Waxler, M. (2002): Accomparactive study of the self consept and aspiration, Journal and educational Research V. 198 N3. 